\title{
ОСОБЕННОСТИ ГЕНЕЗИСА КОНВОЛЮЦИЙ В ОЗЕРНЫХ КОМПЛЕКСАХ РЕГИОНОВ СО СРАВНИТЕЛЬНО НИЗКОЙ (БАЛТИЙСКИЙ ЩИТ) И ВЫСОКОЙ (ТЯНЬ- ШАНЬ) ПАЛЕОСЕЙСМИЧЕСКОЙ АКТИВНОСТЬЮ
}

\author{
Горбатов Е. С., Корженков А. М., Колесников С. Ф., Рассказов А. А., Родина С. Н., Варданян А. А.
}

\begin{abstract}
Аннотация
Проведено структурно-литологическое сравнение внутриформационных пликативных деформаций разжижения (конволюций) в позднечетвертичных озерных образованиях Балтийского щита (отложения малых ледниковых озер) и Тянь-Шаня (отложения крупного стационарного бассейна в Иссык-Кульской впадине) с целью уточнения их генезиса. Регионы имеют резко различные уровни сейсмотектонической активности, что позволяет наиболее полно проследить роль сейсмического фактора в формировании нарушений слоистости. Конволюции Балтийского щита представлены знаками нагрузки, структурами пламени, псевдонодулями, регулярными складками с более выраженными антиклинальными изгибами. Показано, что конволюции здесь возникают только в наиболее разжижаемых грунтах (алевритах и мелкозернистых песках) с низкой когезией и флюидной проницаемостью, при неустойчивой (увеличение плотности и погрубение осадка снизувверх) или нейтральной (однородный состав) стратификации слабоконсолидированных осадков, а соотношение длин синклинальной и антиклинальной части складок (Ксин) для этих структур составляет 1-7.5. Данные признаки указывают на формирование нарушений за счет самопроизвольной или инициированной слабыми механическими воздействиями конвективной неустойчивости в осадочной толще, в условиях нормального вертикального градиента вязкости осадка. Во втором регионе деформации представлены наряду со структурами, типичными для Балтийского щита, и столбчатыми структурами глубокого взаимного внедрения слоев, диапирами и кластическими дайками. Здесь также присутствуют тектонические складки продольного изгиба с Ксин 1, которые формируются при бо́льшей степени консолидации осадков, чем собственно структуры разжижения. Конволюции Иссык-Кульской впадины развиты не только в песчаноалевритовых отложениях, но и в малоразжижаемых грунтах (глина, гравий, галька). Эти структуры формируются как при неустойчивой, так и при устойчивой плотностной стратификации осадка (например, глины-на-песках), а Ксин=0.3-2.5. Таким образом, формирование конволютных структур Иссык-Кульской впадины невозможно без сильных динамических воздействий на стратифицированные осадки в период их накопления. Полученные результаты позволили обосновать преимущественно диагенетический (конвективный и оползневой) генезис конволюций в озерных комплексах Балтийского щита и сейсмогенный - в лимногенных отложениях ТяньШаня. Предложен ряд новых критериев для выделения сейсмитов, что определило практическую значимость исследования.
\end{abstract}

\section{Ключевые слова:}

Озерные отложения, деформационные структуры, конволюции, сейсмиты, разжижение слабоконсолидированных осадков, конвективная неустойчивость, вертикальный градиент плотности осадков, палеоземлетрясения, Балтийский щит, Иссык-Кульская впадина 


\title{
ОСОБЕННОСТИ ГЕНЕЗИСА КОНВОЛЮЦИЙ В ОЗЕРНЫХ КОМПЛЕКСАХ РЕГИОНОВ СО СРАВНИТЕЛЬНО НИЗКОЙ (БАЛТИЙСКИЙ ЩИТ) И ВЫСОКОЙ (ТЯНЬ-ШАНЬ) ПАЛЕОСЕЙСМИЧЕСКОЙ АКТИВНОСТЬЮ
}

\author{
Е.С. Горбатов, А.М. Корженков, С.Ф. Колесников*, А.А. Рассказов ${ }^{* *}$, С.Н. Родина, А.А. \\ Варданян
}

Институт физики Земли им. О.Ю. Шмидта РАН, 123242, Москва, ул. Б. Грузинская, 10, Россия

*Московский государственный университет геодезии и картографии (МИИГАиК), 105064, Москва, Гороховский пер., 4, Россия

** Российский университет дружбы народов, 117198, Москва, ул. Миклухо-Маклая, 6, Россия

Проведено структурно-литологическое сравнение внутриформационных пликативных деформаций разжижения (конволюций) в позднечетвертичных озерных образованиях Балтийского щита (отложения малых ледниковых озер) и Тянь-Шаня (отложения крупного стационарного бассейна в Иссык-Кульской впадине) с целью уточнения их генезиса. Регионы имеют резко различные уровни сейсмотектонической активности, что позволяет наиболее полно проследить роль сейсмического фактора в формировании нарушений слоистости. Конволюции Балтийского щита представлены знаками нагрузки, структурами пламени, псевдонодулями, регулярными складками с более выраженными антиклинальными изгибами. Показано, что конволюции здесь возникают только в наиболее разжижаемых грунтах (алевритах и мелкозернистых песках) с низкой когезией и флюидной проницаемостью, при неустойчивой (увеличение плотности и погрубение осадка снизу-вверх) или нейтральной (однородный состав) стратификации слабоконсолидированных осадков, а соотношение длин синклинальной и антиклинальной части складок $\left(\mathrm{K}_{\text {син }}\right)$ для этих структур составляет 1-7.5. Данные признаки указывают на формирование нарушений за счет самопроизвольной или инициированной слабыми механическими воздействиями конвективной неустойчивости в осадочной толще, в условиях нормального вертикального градиента вязкости осадка. Во втором регионе деформации представлены наряду со структурами, типичными для Балтийского щита, и столбчатыми структурами глубокого взаимного внедрения слоев, диапирами и кластическими дайками. Здесь также присутствуют складки продольного изгиба с $\mathrm{K}_{\text {син }} \sim$, которые формируются при бо́льшей степени консолидации осадков, чем собственно структуры разжижения. Конволюции Иссык-Кульской впадины развиты не только в песчано-алевритовых отложениях, но и в сравнительно малоразжижаемых грунтах (глина, гравий, галька). Эти структуры формируются как при неустойчивой, так и при устойчивой плотностной стратификации осадка (например, глины-на-песках), а $\mathrm{K}_{\text {син }}=0.3-2.5$. Таким образом, формирование конволютных структур Иссык-Кульской впадины невозможно без сильных динамических воздействий на стратифицированные осадки в период их накопления. Полученные результаты позволили обосновать преимущественно диагенетический (конвективный и оползневой) генезис конволюций в озерных комплексах 
Балтийского щита и сейсмогенный - в лимногенных отложениях Тянь-Шаня. Предложен ряд новых критериев для выделения сейсмитов, что определило практическую значимость исследования.

Озерные отложения, деформационные структуры, конволюции, сейсмиты, разжижение слабоконсолидированных осадков, конвективная неустойчивость, вертикальный градиент плотности осадков, палеоземлетрясения, Балтийский щит, Иссык-Кульская впадина

\title{
PECULIARITIES OF THE GENESIS OF CONVOLUTIONS IN LACUSTRINE COMPLEXES OF REGIONS WITH A RELATIVELY LOW (BALTIC SHIELD) AND HIGH (TIAN-SHAN) PALEOSEISMIC ACTIVITY
}

\author{
E.S. Gorbatov, A.M. Korzhenkov, S.F. Kolesnikov, A.A. Rasskazov, S.N. Rodina, A.A. \\ Vardanyan
}

Structural and lithological comparison of intraformational plicative liquefaction softsediment deformation structures (convolutions) in Late Quaternary lacustrine formations of the Baltic Shield (deposits of small glacial lakes) and Tian-Shan (deposits of a large stationary basin in the Issyk-Kul depression) was carried out in order to clarify their genesis. The regions have sharply different levels of seismotectonic activity, which made it possible to trace the role of the seismic factor in the formation of bedding disturbances. Convolutions of Baltic Shield are represented by load casts, flame structures, pseudonodules, regular folds with more pronounced anticlinal bends. It is shown that convolutions here occur only in the most liquefied soils (silts and fine-grained sands) with low cohesion and fluid permeability, with unstable (increase in density of sediment from bottom to top) or neutral (homogeneous composition) stratification of weakly consolidated sediments, and the ratio of the lengths of the synclinal and anticlinal parts folds $\left(\mathrm{C}_{\text {syn }}\right)$ for these structures is 1-7.5. These signs indicate the formation of disturbances due to spontaneous or initiated by weak mechanical effects of convective instability in the sedimentary strata under conditions of a normal vertical gradient of sediment viscosity. In the second region, deformations are represented, along with the liquefaction structures typical of the Baltic Shield, as well as columnar structures of deep interpenetration of layers, diapirs and clastic dikes. There are also flexural folds with $\mathrm{C}_{\mathrm{syn}} \sim 1$, which are formed at a greater degree of sediment consolidation than the liquefaction structures proper. Convolutions of the Issyk-Kul depression are developed not only in sandy-silty sediments, but also in low-liquefied soils (clays, gravel, pebbles), these structures are formed both during unstable and stable density stratification of sediment (for example, clay-on-sand), and $\mathrm{C}_{\text {syn }}=0.3-2.5$. Thus, the formation of convolute structures of the Issyk-Kul depression is impossible without strong dynamic effects on stratified sediments during the period of their accumulation. The results obtained made it possible to substantiate the predominantly diagenetic (convective and landslide) genesis of convolutions in the lacustrine complexes of the Baltic Shield and seismogenic in limnogenic deposits of the Tien-Shan. A number of new criteria for identifying seismites were proposed, which determined the practical significance of the study.

Lacustrine sediments, soft-sediment deformation structures, convolutions, seismites, liquefaction of weakly consolidated sediments, convective instability, vertical gradient of sediments density, paleoearthquakes, Baltic Shield, Issyk-Kul depression 


\section{ВВЕДЕНИЕ}

Синседиментационные и раннедиагенетические деформационные структуры широко распространены в осадочных породах и рыхлых слаболитифицированных отложениях и обозначаются в англоязычной литературе последних лет термином «softsediment deformation structures - SSDS» [Moretti, 2000; Moretti, Sabato, 2007; Van Loon, 2009, 2014 Shanmugan, 2017]. Они описаны в различных фациальных обстановках, в частности, в озерных слоях. Их образование связывается с процессами потери прочности и разжижения отложений в сочетании с вязкопластичными течениями [Lowe, 1975] под действием как сейсмических [Hempton and Dewey, 1983; Scott and Price, 1988; Calgue et al., 1992], так и нетектонических факторов [Ботвинкина, 1962; Alfaro et al., 2002]. Особенно характерны такие структуры для высокодисперсных отложений озерного генезиса переслаивающихся глин, алевритов и песков. Для обозначения всего многообразия пликативных деформационных структур в статье мы используем более компактный термин «конволюции», под которым следует понимать локализованные в горизонтах пластичные деформации, развитые в пределах слоя или пачки слоев, с резким смятием отдельных слойков, связанные с процессами разжижения и оползания осадков.

Сейсмогенные конволюции или сейсмиты возникают в эпицентральных областях сильных землетрясений при распространении в них высокодисперсных обводненных осадков. Они могут быть развиты на бо́льших площадях, чем первичные сейсмотектонические дислокации, а также иметь большую сохранность в разрезах осадочных формаций и в ряде случаев легче поддаваться датированию. Поэтому анализ сейсмитов очень информативен при изучении палеосейсмической активности регионов. Однако выделение вторичных сейсмогенных структур в рыхлых отложениях среди деформаций нетектонического генезиса зачастую является сложной задачей [Shanmugan, 2016]. Предлагаемым путем решения этой проблемы может быть сравнение деформационных структур в озерных отложениях в активном горно-складчатом регионе с высоким (Тянь-Шань) и платформенном регионе со сравнительно слабым (Балтийский щит) уровнем палеосейсмической активности.

Исследованные литологические разности в обоих регионах представлены сходными по составу дисперсными отложениями, склонными к процессам разжижения, в том числе под действием сейсмического фактора. Северный Тянь-Шань - один из наиболее сейсмически активных регионов мира и известен своими сильными землетрясениями магнитудами 8 и более. Поэтому в разрезах рыхлых отложений этого региона следует ожидать обилие сейсмогенных нарушений. Наши исследования деформационных структур в четвертичных озерных комплексах Иссык-Кульской впадины (Северный Тянь-Шань) позволило не только доказать их сейсмическую природу, но и значительно продлить в прошлое запись сейсмической активности [Корженков и др., 1999; Bowman et al., 2004; Поволоцкая и др., 2006; Gladkov et al., 2016; Корженков и др., 2018; Deev et al., 2018, и др.]. На территории Балтийского щита, где современная сейсмическая активность невысока, а вопрос о возможности возникновения здесь высокомагнитудных палеоземлетрясений в прошлом остается дискуссионным, для отнесения выделяемых здесь конволюций к категории сейсмитов необходимы веские основания. В частности, наши исследования [Горбатов и др., 2017; Горбатов и др., 2020] показывают, что в 
отдельных сейсмогенерирующих структурах региона (Кандалакшский грабен), выраженных в рельефе, предполагаемые палеосейсмодислокации могут отвечать событиям умеренных магнитуд $(\mathrm{M} \leq 5.0-5.5)$, при которых обычно не происходит формирование сейсмитов. Вместе с тем зачастую разнообразные деформационные структуры, выявляемые в рыхлых отложениях Балтийского щита и смежных районов Восточно-Европейской платформы, относят к результату сильных палеоземлетрясений с M=6-8 [Никонов, 2003; Николаева, 2009; Бискэ и др., 2009; Шварев, 2019 и др.]. Однако, как будет показано в статье, при частичном сходстве конволютных структур в двух регионах, их вариабельность по морфологии, кинематическим особенностям формирования деформаций, литологическому составу вмещающих отложений и их физико-механическим свойствам в момент формирования нарушений в этих регионах сильно различается, что позволяет предполагать различный генезис этих структур.

Цель работы - комплексное сравнение конволюций в двух регионах с различным уровнем палеосейсмической активности для уточнения генетических особенностей этих деформационных структур. Это позволяет, с одной стороны, установить происхождение конволюций в озерных комплексах Балтийского щита, которые некоторые исследователи считают сейсмитами, а с другой, - дополнительно проверить сейсмогенность конволюций Тянь-Шаня, а также уточнить существующие критерии для выделения сейсмитов. Характер фактического материала позволяет нам рассмотреть в данной работе только пликативные структуры, связанные с разжижением осадков без существенного латерального течения и оползания.

Методика исследования. Для поиска перспективных обнажений использовались методы геоморфологического дешифрирования космических снимков, позволившие составить схемы четвертичных отложений районов исследования (рис. 1, фрагменты А1A3, Б). Четвертичные отложения изучались в обнажениях путем подробного фотографирования и выполнения зарисовок в естественном препарированном виде или после детальной зачистки, в зависимости от степени выраженности слоистости. Составлялись общие разрезы или литологические колонки и их подробные описания, в которых отражались условия залегания, мощность, состав и текстура осадков. Путем изучения текстурных особенностей отложений анализировались седиментационные обстановки, в частности динамика водной среды при накоплении осадков и признаки криогенного преобразования материала. Для конволютных структур фиксировались следующие параметры: мощность и латеральная протяженность деформационных горизонтов, регулярность деформационных структур, морфология и размер структур, форма складок, их асимметрия и вергентность, степень проникновения и изоляции, состав деформированных и вмещающих отложений и характер затухания деформаций к кровле и подошве горизонтов. В ходе исследования введен количественный показатель геометрических соотношений антиклинальных и синклинальных складок в горизонтах регулярных конволюций, который указывает на их генетические особенности. При анализе плотностной стратификации отложений и возможности самопроизвольного формирования деформаций проведены лабораторные определения плотности водонасыщенных осадков разного гранулометрического состава. Пробы были отобраны из деформационных горизонтов в изученных обнажениях. Плотности замерялись после осаждения взмученного осадка, в диапазоне консистенций: от суспензии до 
консолидированного осадка, в котором, вероятнее всего, находились грунты в период формирования деформаций.

\section{УСЛОВИЯ ФОРМИРОВАНИЯ ЧЕТВЕРТИЧНЫХ ОЗЕРНЫХ КОМПЛЕКСОВ ДВУХ РЕГИОНОВ}

Вскрытые в карьерных разрезах Балтийского щита, наиболее пригодных для изучения деформационных структур, озерные отложения $\left(\mathrm{Q}_{3}\right)$ представлены тремя типами образований, отвечающих относительно глубоководным и застойным ледниковоподпрудным озерам, крупным приледниковым бассейнам и малым проточным внутриледниковых водоемам. Первые образования отличаются наиболее тонким составом осадков, преобладанием горизонтальной слоистости ленточного типа, наличием дропстоунов. Данный тип отложений с комплексом гравитационных нарушений наблюдался нами в основании разреза четвертичных отложений, вскрытых карьером «Коашва» в Южных Хибинах [Горбатов, Колесников, 2016]. Второй тип образований наиболее характерен для разрезов озерно-ледниковых равнин и вскрыт карьером «Половина» (рис. 1, фрагмент А3). Они отличается песчано-алевритовым составом, выдержанным по простиранию залеганием слоев, горизонтальной или слабонаклонной и в меньшей степени волнистой и косоволнистой текстурой осадков. Образования третьего генетического типа включают в себя относительно маломощные прослои и линзы озерных осадков во флювиогляциальных и моренных комплексах. Наиболее характерная черта состава этих отложений - преобладание песков и алевритов, практически полное отсутствие глинистых разностей, полное отсутствие органики, тонкая ленточная слоистость, широкое развитие волнистых и косоволнистых текстур, отсутствие дропстоунов, указывающих на малую глубину бассейнов седиментации и активность донных течений. Озерные отложения этого типа зачастую имеют наклонную облекающую слоистость, что обусловлено сложным рельефом в период осадконакопления. Данный тип накоплений отмечен в разрезах «Тирвас» и «Шарваозеро».

Озеро Иссык-Куль занимает значительную часть одноименной внутригорной тектонической впадины, ограниченной конвергентными взбросами [Корженков и др., 2018]. Впадина выполнена полифациальными континентальными накоплениями молассового облика, причем, начиная с олигоцена, осадконакопление в ней происходило на фоне интенсивного орогенического поднятия территории, отмеченного огрубляющимися вверх по разрезу осадками мощностью 4000 м. Озеро в Иссык-Кульском внутригорном бассейне существует с ранненеогеновой эпохи. Четвертичные накопления включают широкой спектр отложений от тонких озерных глин до гигантских моренных глыб, а озерные фации представлены глинами, песками, телами песчано-гравийных береговых валов, а также мергелями и выполняют значительную часть впадины (рис. 1, фрагмент Б). Слоистость в озерных комплексах преимущественно горизонтальная, волнистая (знаки ряби волнения), реже косая. Поскольку осадконакопление происходит в крупном озерном бассейне, слои выражены по простиранию, первичные границы между слоями чаще всего горизонтальные, а наклонное залегание, как правило, имеет вторичный характер и обусловлено тектоническим перекосом. 


\section{Балтийский щит.}

Разрез кукисвумской моренной гряды «Тирвас» (Южные Хибины). В обнажениях на территории профилактория «Тирвас» нами исследовано строение проксимального склона моренной гряды (местоположение см. на рис. 1, фрагменты А, A1), образовавшейся в ранневалдайское время (МИС 4) в результате длительной остановки языка покровного ледника, вторгшегося в межгорную впадину Хибин. Сверху вниз по разрезу отмечается постепенный переход частично перемытой морены во флювиогляциальные отложения со слоями и линзами лимногляциальных осадков (рис. 2). Ранее (2015 год) было описано обнажение в основании гряды с нерегулярными конволюциями в кровле слоя мелкозернистых песков [Горбатов и др., 2019]. В ходе повторного осмотра выработки в 2018 году описана новая стенка (GPS координаты N67³9.24' Е33³9.68'), вскрывающая лимногляциальные и флювиогляциальные осадки, в которых верхний горизонт деформаций выражен значительно лучше, а также выявлен второй горизонт конволюций. Разрез имеет следующее строение (слои 1, 4 - флювиогляциального генезиса, остальные лимнические):

Слой 1 - неслоистый ожелезненный галечно-гравийно-песчаный материал, преходящий книзу в слоистые гравийно-песчаные и песчаные отложения с линзами крупнозернистых песков. Общая мощность слоя - 50-60 см, в ЮВ части обнажения слой выклинивается.

Слой 2 - мелкозернистый алевритистый песок генезиса с тонкими прослоями алевритов общей мощностью 20-25 см, деформированный в верхней части слоя с образованием регулярных изоклинальных, сжатых и веерообразных антиклинальных складок (язычков) длиной 6-8 см и шагом 15-30 см, опрокинутых по восстанию слоя на С3, и широких синклинальных складок. Складки плавно затухают к подошве и без размыва перекрываются гомогенными песками со слабо различимой нарушенной слоистостью. В промежутках между некоторыми складками «висят» шары песка с концентрической слоистостью. Выступающие гребни антиклинальных складок не срезаны и облекающее перекрыты однородными песками с нечеткой слоистостью и бо́льшим содержанием алевритов. Песок в нижней части слоя имеет ненарушенную слабо смещенную параллельно-волнистую слоистость. В ЮВ части слоя складки резко затухают, а слоистость становится субгоризонтальной.

Слой 3 - слоистый алеврит со слабо смещенной на С3 волнистой слоистостью (восходящие знаки ряби) с прослоем среднезернистых песков с косоволнистой слоистостью, которые фациально замещаются по латерале алевритами. Мощность слоя 25-33 см.

Слой 4 - неслоистый гравелистый песок мощностью 7-14 см;

Слой 5 -мелко- среднезернистый песок с волнистой сильно смещенной (срезанной) слоистостью. В верхней части слоя развит выдержанный по простиранию горизонт крупных конволюций в виде сжатых и веерообразных (часто дивергентно раздвоенных) небольших антиклинальных складок длиной 5-15 см и участков хаотичного перемешивания. Складки расположены нерегулярно, отличаются большими вариациями в морфологии и размерах и перекрыты однородными песками с нечеткой первичной слоистостью и с бо́льшим содержанием алевритов. Выделяются отдельные псевдонодули и шары размером 5-20 см с концентрической слоистостью или однородные по текстуре, 
отдельные из которых сложены более крупнозернистыми песками, чем вмещающий материал. Кровля гомогенизированных мелкозернистых песков ровная. Слой нарушен тремя субгоризонтальными разрывами, прослеженными на расстоянии до 3 м, отличающимися высокой прямолинейностью и незначительными смещениями (до $1 \mathrm{~cm})$. С востока на запад общая мощность слоя уменьшается с 60 до 30 см, мощность конволютного горизонта - с 30 до 20 см.

Слой 6 - алевритистый песок с слабосмещенной волнистой слоистостью, переходящий книзу в алеврит с пологоволнистой ленточной слоистостью. В слое выявлена цепочка крупных линз среднезернистых песков с косой слоистостью. Кровля слоя подчеркнута маркирующим прослоем алевритов, отличающимся плавной волнистой морфологией в ЮВ части обнажения и нерегулярными деформационными изгибами с образованием островершинных язычков в СЗ части обнажения, однако слоистость перекрывающих песков на контакте остается недеформированной. Общая мощность слоя - 25-35 см.

Слои 7-8 - чередование пакетов ленточных суглинков с волнистой и горизонтальной слоистостью и крупнозернистых песков со слоистостью, в которой отмечается выклинивание слойков к подошве под очень пологим углом.

Разрез камовой гряды «Шарваозеро» (Северная Карелия). Обнажение с крупными конволюциями выявлено в центральной части старого участка карьера «Шарваозеро» в

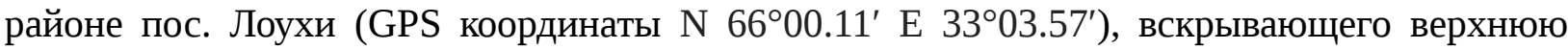
часть разреза радиальной камообразной гряды [Горбатов, 2020]. В разрезе (рис. 3, фрагмент I) выявлено два участка развития крупных и регулярных конволюций, которые ограничены сверху и снизу ненарушенными отложениями, накопившимися до и после деформационного события. Первый (восточный) участок протяженностью 5 м (расчистки «а», «б» на рис. 3) развит в верхней части слоя опесчаненных алевритов и вскрыт в двух сечениях. Мощность деформационного горизонта на нем повышается с запада на восток от 0.2 до 1.2 м. Деформационные структуры на втором участке протяженностью 8 м в центральной части разреза (участок «в») отмечены на границе слоя мелкозернистых песков, перекрывающих алевриты.

Участок «а» деформационного горизонта мощностью 20-120 см, протяженностью 5 м вскрыт в уступе субмеридионального простирания, примыкающим под прямым углом к уступу, разрез которого показан на верхнем рисунке. Складчатые деформации представлены прямыми и опрокинутыми в направлении падения слоистости открытыми антиклинальными складами, разделенными более широкими синклинальными изгибами, имеющими меньшую амплитуду. Амплитуда первых 50-120 см, а шаг - 50-100 см. Некоторые антиклинальные складки по форме замка изменяются от острых до округлых вверх по горизонту. Складчатость плавно затухает к подошве, деформации без размыва и облекания выступающих частей перекрываются ненарушенными слоистыми отложениями, причем складки затухают на разных стратиграфических уровнях. Деформации развиты в однородных, тонкослоистых отложениях. Псевдонодули и гомогенизированные отложения, характерные для других участков разреза, здесь отсутствуют.

На участке «б» отмечена крупная вертикальная антиклинальная складка амплитудой 1.4 м с верхней частью, опрокинутой на запад. Структура ограничена по латерали синклинальными складочками и рулонными псевдонодулями. Алевриты, выполняющие 
синклинальные складочки, отличаются большим содержанием песков и имеют более светлый оттенок по сравнению с отложениями, вовлеченными в восходящее внедрение. По подошве горизонта деформаций отмечено залегание на подстилающх ненарушенных горизонтально-слоистых песчано-алевритовых отложениях с угловым несогласием, т.е., перед формированием деформаций имел место перерыв осадконакопления.

На центральном участке обнажения «в» мощность конволюций превышает 3 м в его восточной части, где деформации отличаются сложностью и хаотичностью, и далее к западу сокращается до 0.4-0.2 м, а нарушения приобретают вид хорошо выраженного горизонта. Горизонт залегает несогласно на подстилающих отложениях, с востока замешается ненарушенными отложениями, а с запада постепенно выклинивается. Горизонт конволюций состоит их антиклинальных сжатых и нормальных прямых и опрокинутых складок амплитудой 10-20 см и шагом 25-45 см, сложенных алевритами, разделенных пологими и веерообразными синклинальными складочками, сложенными мелкозернистыми песками. Вергентность отсутствует. Выступающие части складок полностью перекрыты гомогенизированным песком, в котором отмечено также несколько изолированных подушек и капелевидных псевдонодулей с синклинальным типом внутренней структуры. Подушки поперечным сечением 0.4-0.8 м имеют округлое основание и ровную кровлю, перекрытую недеформированными горизонтальнослоистыми песками.

На новом карьере, вскрывающим склон камообразной гряды, выявлены песчаноалевритовые отложения мощностью до 0.5 м, залегающие под чехлом грубообломочных флювиогляциальных отложений, замещающихся $\mathrm{K}$ основанию склона гряды мореноподобными образованиями. В одной из расчисток обнаружено переслаивание алевритов и косоволнистых средне-крупнозернистых песков, причем в подошве и кровле верхнего слоя алевритов мощностью 0.25 м выявлены два горизонта мелких конволюций мощностью 7 и 12 см. (рис. 4). Деформационные структуры подчеркнуты светло-серыми прослоями глинистых алевритов, охватывают только слой алевритов и не продолжаются в песчаных отложениях. Верхний горизонт представлен регулярными прямыми закрытыми антиклинальными складки амплитудой 2 см и шагом 7 см, разделенные открытыми синклинальными изгибами, развитыми по первичной параллельно-волнистой слоистости осадка. Нижний горизонт, отличается более хаотичными и нерегулярными складками, а также наличием отдельных псевдонодулей.

Разрез озерно-ледниковой равнины в районе д. Половина (Южная Карелия). Очень крупные, но нерегулярные структуры внедрения выявлены в карьере вблизи д. Половина, в 20 км к западу от г. Петрозаводск (GPS координаты N 6148.25'E 3354.27'). Сводный разрез имеет следующее строение (отметки глубин даны от поверхности):

0-20 см (местами до 150 см) - крупнозернистые флювиогляциальные пески с прослоями гравия, образующие срезающие друг друга косослоистые серии. Нижняя граница слоя - неровная и резкая.

20-250 см - однородный среднезернистый песок лимнического генезиса со слойками алевритов мощностью 5-10 см с волнистой слоистостью, нарушенный сеткой тонких вертикальных трещин с темно-серым суглинистым заполнителем.

220-250 см и ниже - плотный глинистый алеврит лимнического генезиса с прослоями мелкозернистого песка и резко выраженной и сильно деформированной верхней границей, перекрытые нарушенными песками. Горизонт конволюций имеет 
мощность 20-40 см и не выдержан по простиранию, а интенсивность деформации сильно варьирует по литерали. В перекрывающем слое содержатся фрагменты алевритов неправильной формы, которые могли быть захвачены как из нижележащего слоя, так и сформироваться in situ из маломощных прослоев алеврита в толще песков (рис. 5, А). Деформации представлены антиклинальными складками различной морфологии. Это две открытые прямые складки амплитудой 10 и 15 см, узкая лежачая складка длиной 60 см (рис. 5, В), опрокинутая против направления падения слоя, серия небольших антиклинальных внедрений высотой 5 см и шагом 10 см, «висящих» в толще песков, внедрение в виде трехлучевой звезды с заостренными лучами (рис. 5, С).

\section{Иссык-Кульская впадина (Северный Тянь-Шань).}

Кок-Мойнокской разрез. Обследованный разрез (GPS координаты N42²7.30' E7606.20') в Кок-Мойнокской впадине представлен чередованием хорошо стратифицированных слоистых песков, алевритов, глин и песчано-галечных слоев [Корженков и др., 2018]. Отложения накоплены в позднеплейстоценовом палеозаливе озера Иссык-Куль, расположенном в западной части его котловины. Циклический характер переслаивания алевритов, глин и песка, часто с галькой, указывает на фациальные флуктуации между мелководными озерными, пляжевыми и аллювиальными обстановками. В 126-метровой толще осадков Кок-Мойнокского разреза встречено пять горизонтов конволютных структур различной морфологии и состава, вовлеченных в деформацию осадков (рис. 6, I).

Первый снизу горизонт конволюций «А» общей мощностью до 1.5 м и видимой латеральной протяженностью 50 м развит в слое глин с маломощными прослоями песка и песчаных галечников в кровле (рис. 6, А). Горизонт представляют собой волнообразные деформации умеренной интенсивности в его нижней и средней части (длин волн - 80100 см, амплитуда - 20-25 см, морфология ассиметричная, северовергентная) и глубокими деформациями с сильными изменениями мощности слоев на границе верхнего слоя глин, перекрытых галечникам. В отдельных случаях части гребней антиклиналей в прослоях песков оторваны и образуют изолированные линзовидные капли.

Горизонт «Б» представлен чередованием маломощных слоев мелкой гальки, песков и глин. Здесь выявлено три сближенных подгоризонта конволюций, разделенных слабонарушенными отложениями с горизонтальной слоистостью. Первый подгоризонт мощностью 75 см развит на границе среднезернистого песка, перекрытого глинами и имеет вид выжатых вверх наклонных столбиков песка высотой до 90 см и шагом 20-45 см. Второй подгоризонт мощностью 50 см развит в переслаивающихся слоях песка, глины и мелкой гальки (три маркирующих прослоя) и имеет вид волн длиной 30-33 см и амплитудой - до 24 см. Третий подгоризонт аналогичен первому по морфологии и составу вмещающих отложений, высота столбиков - до 25 см, их ширина - до 10 см, шаг - 1025 см. Все столбики наклонены в северном направлении и имеют в верхней части каплевидную форму с отрывами фрагментов слоя песка (рис. 6).

Горизонт «В» общей мощностью 1.25 м состоит из трех сближенных подгоризонтов волнообразных конволюций в слое песков, переславивающихся с глинами, причем деформации развиты только на границе песков, перекрытых глинами и плавно затухают к смежным по вертикале границам, на которых глины перекрываются песками без деформаций. Горизонт конволюций перекрыт недеформированными галечниками. Средняя длина волн $12 \mathrm{~cm}$, амплитуда $5 \mathrm{~cm}$, отмечается северная вергентность. В 
продолжении горизонта по латерали имеются многочисленные структуры прорыва песчаников подстилающими глинами в форме дивергентных грибовидных структур и подушек.

Горизонт «Г» общей мощностью 1.8 м развит в пачке переслаивающихся маломощных слоев песка и глины. Здесь выявлен комплекс симметричных волнообразных конволюций длиной 30 см, высотой - до 40 см, причем степень деформации максимальна в кровле первого прослоя песка, быстро затухает к его подошве и медленно - к кровле четвертого прослоя песка.

Самый верхний в разрезе горизонт «Д» мощностью 2 м представлен деформациями на границе массивных глинистых отложений перекрытых толщей гравийно-галечников, в которые последние внедрены в виде капель. Вдоль разреза на протяжении 300 м горизонт переходит в конволюции в форме отдельных лежачих антиклиналей длиной до 2 м, возникающих при внедрении песков в перекрывающие глины, на эрозионном контакте которых залегают аллювиальные позднечетвертичные валунники.

Прибрежные разрезы позднеплейстоцен-голоценовых отложений. В изученных разрезах на побережье оз. Иссык-Куль представлено чередование хорошо стратифицированных или слоистых песков, алевритов, глин и песчано-галечных слоев, часто демонстрирующих волнистое напластование, косую слоистость, а иногда и массивную текстуру. Подобное циклическое напластование глин, алевритов и песка, часто с линзами и прослоями галечников, указывают на динамические фациальные флуктуации между мелководными озерными, пляжными и флювиальными обстановками. Изучены следующие разрезы с указанием GPS координат, возраста и абсолютных отметок: Актерекский (N42 $14.87^{\prime}$ E76²42.78'; 24-10 тыс. лет назад, 1624-1636 м над у.м.), БозБармакский (N42²4.49' E7606.33'; 24 тыс. лет назад; 1640 м над у.м.); Ирдыкский (N42³2.35' E78¹5.10'; 26-19 тыс. лет назад, 1627-1637 м над у.м.) и Чоктальский (N42³4.97' E76²43.91'; 11.2-10.6 тыс. лет назад, 1612-1614 м над у.м.), а также обнажение близ с. Кошкель (N42³2.11' E76³6.56', Q4, 1625 м над у.м.) [Корженков и др., 2018].

В прибрежных разрезах выявлены следующие типы деформаций: регулярные изолированные псевдонодули, отделенные диапировые структуры, гигантские уплощенные подушки, прямые и вергентные столбчатые конволюции, а также сложные деформации с хаотичными опрокинутыми складкам (рис. 7). Отмечено, что деформации с нарушением сплошности перекрывающего слоя (в виде шаров и подушек) формируются в системах «илы-на-песках» или «пески-на-илах» и зачастую имеют эродированную кровлю, а столбчатые конволюции, как правило, образуются только в системах «илы-напесках» и их формирование не заканчивается размывом. B разрезе Боз-Бармак [Deev et al., 2018] наряду с пликативными структурами отмечены горизонты регулярных песчаных диапиров длиной 5-12 см и шагом 10-20 см, возникающие на границе песков, перекрытых алевритами.

\section{СРАВНИТЕЛЬНАЯ ХАРАКТЕРИСТИКА КОНВОЛЮТНЫХ СТРУКТУР}

В данном разделе представлена сравнительная характеристика деформационных структур в изученных разрезах и интерпретация наиболее значимых генетических различий. Подробная характеристика деформационных структур конкретных изученных разрезов была представлена выше. Обобщенная сравнительная характеристика деформационных структур рассматриваемых регионов приводится в таблице. 
Различия в латеральной протяженности и количестве деформационных горизонтов связаны в первую очередь с характером исходного залегания вмещающих деформации слоев и разной частотой возникновения деформационных событий, и, на наш взгляд, не могут служить основными характеристиками генезиса нарушений. Так, высокая латеральная протяженность горизонтов деформации в отложениях Иссык-Кульской впадины по сравнению с конволюциями Балтийского щита обусловлена выдержанным по простиранию характером залегания слоев озерных отложений, накопленных в крупном стационарным бассейне.

Необходимо отметить меньшее разнообразие типов деформационных структур для разрезов на Балтийском щите и большие вариации в морфологии складчатых структур в Иссык-Кульской впадине. В частности, в разрезах четвертичных озерных отложений ТяньШаня, кроме структур пламени и псевдонодулей широко представлены структуры глубокого проникновения слоев (столбы, «выпрыгивающие змеи»), а также дипиры. Повидимому, для формирования второй группы структур необходимы значительные внешние динамические воздействия, что характерно для регионов с высокой сейсмичностью.

Сравнивая отношение ширины синклинальных и антиклинальных частей складок (коэффициент синклинальности - $\mathrm{K}_{\text {син }}$ ) в горизонтах регулярных конволюций, можно отметить заметные различия этого показателя, что позволяет рассматривать его в качестве генетического (табл. 1). На Балтийском щите отмечается заметная зауженность антиклинальных складок по сравнению с синклинальными ( $\mathrm{K}_{\text {син }}$ выше 1$)$, в Иссык-

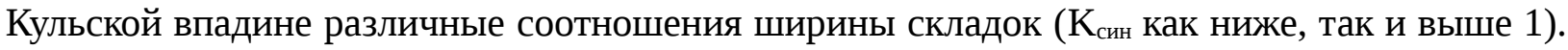
Данные различия могут быть следствием различного происхождения складок. В первом регионе складки имеют в основном конвективную природу (конволюции могут быть инициированы даже слабыми механическими воздействиями) и возникают при определенном соотношении плотности и вязкости слоев, на границе которых они формируются. Во втором регионе $\mathrm{K}_{\text {син }}$ более вариабельный в связи с наличием нескольких механизмов формирования деформаций - разжижения принудительного (сейсмогенного), самопроизвольного (диагенетического) и горизонтального укорочения сейсмовибрационной природы, а деформации возникают при разных соотношениях физических свойств (пластичность, вязкость) осадков смежных слоев.

Сравнивая особенности перехода деформированной слоистости в ненарушенную по вертикали, можно отметить следующее. Для разрезов Балтийского щита характерна высокая степень сохранности складок в верхней части горизонта, часто перекрытых гомогенными осадками или плавно затухающих к границам, тогда как в разрезах ИссыкКульской впадины зачастую наблюдаются частичный размыв кровли складчатого горизонта. Это различие можно объяснить, с одной стороны большей скоростью и интенсивностью процессов формирования нарушений во втором регионе, что не противоречит их сейсмогенности. С другой стороны, на Балтийском щите отложения, в которых сформировались деформации, были уже перекрыты к моменту формирования деформаций вышележащими слоями, что и способствовало диагенетическому перемешиванию осадков.

В обоих регионах конволюции возникают, как на границе контрастных по литологическому составу отложений, так и в однородных пачках с тонкой слоистостью. Слоистость осадков до формирования деформаций - горизонтальная, пологонаклонная, пологоволнистая, волнистая смещенная. Однако наиболее существенные различия 
проявляются в литологическом составе отложений, вовлеченных в деформацию. В разрезах Балтийского щита распространенность конволюции в разрезе сильно зависит от состава осадков, и деформационные структуры развиты только в отложениях весьма ограниченного гранулометрического диапазона (от алевритов до среднезернистых песков) при наличии в разрезах отложений от суглинков до валунников. Необходимо отметить, что в этом регионе нами описан еще ряд разрезов со схожим литологическим составом деформированных осадков, не вошедших в настоящую статью из-за отсутствия принципиальных отличий в строении и структуре деформаций от приведенных разрезов [Рассказов, Горбатов, 2019]. Поэтому выявленная региональная закономерность представляется весьма устойчивой. В изученных разрезах высокосейсмичного района Тянь-Шаня деформационные структуры возникают практически в любых частях разрезов и мало зависят от состава вмещающих отложений, а в деформацию вовлечен практически полный спектр отложений - от глин до галечников. Данное принципиальное отличие позволяет предполагать самопроизвольный генезис конволюций в отложениях Балтийского щита, которые развиваются только в дисперсных осадках, наиболее подверженных процессам разжижения при осадконакоплении и раннем диагенезе, тогда как в высокосейсмичных регионах нарушения возникают и в малоразжижаемых отложениях (глинистых и крупнообломочных), что невозможно без внешних динамических воздействий на слабоконсолидированные осадки.

В тех случаях, когда конволюции возникают на границах контрастных по составу осадков, можно проследить влияние плотностной стратификации осадков на встречаемость деформационных структур. В разрезах Балтийского щита деформации наблюдаются, как правило, только в системе: «крупнозернистые осадки на мелкозернистых» или в малоконтрастных по составу отложениях. Такие системы в слабоконсолидированном состоянии осадка обычно обладают неустойчивой (например, пески-на-алевритах) или близкой к нейтральной стратификацией по плотности [Moretti, 1999]. В Иссык-Кульской впадине конволюции наблюдаются зачастую и при неинверсированном (устойчивом) расположении слоев в разрезе (глины или мергели на песках), т.е. в системах в которых конвективные процессы невозможны. При этом интенсивные деформационные структуры здесь наблюдаются и при неустойчивой стратификации - в системах: пески-на-глинистых алевритах или гравий-на-глинистых алевритах. Это отличие, как и предыдущее, подтверждает определяющую роль динамических воздействий в формировании деформационных структур в высокосейсмичном регионе.

Для иллюстрации условий неустойчивой или устойчивой стратификации грунтов в изученных разрезах приведем определенные нами лабораторным путем плотности водонасышенных разжиженных отложений разного гранулометрического состава. Плотности замерялись путем взвешивания осадка после консолидации от взмученного до плотного состояния (осадок не растекается под собственным весом при наклоне сосуда). Для следующих гранулометрических разностей они составили: мелкосреднезернистый

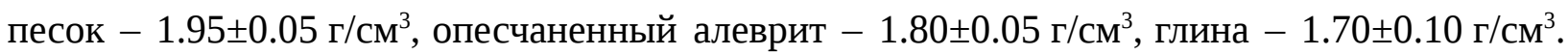
Таким образом, неустойчивая стратификация, чаще всего характерна для систем: «крупнозернистые осадки на мелкозернистых» с обратным градиентом плотности.

Другой специфической чертой деформационных структур Иссык-Кульской впадины является наличие нейтральных $\left(\mathrm{K}_{\text {син }} \sim 1\right)$ волнообразных (гармонических) складок в 
горизонтальных пачках, охватывающих большое количество разнородных по составу слоев и прослоев (Кок-Мойнокский разрез). Характер таких деформаций сложно объяснить только процессами разжижения, поскольку степень деформации мало зависит от состава отложений, а длина складок значительно превышает мощность отдельных прослоев. Поэтому формирование данного типа нарушений, вероятно, происходило под действием латерального сжатия сейсмовибрационной природы, а процессы разжижения и вязкопластичного течения имели здесь второстепенное значение. Похожие структуры на Северо-Западе наблюдались нами только в восточной части старого карьера «Шарваозеро», однако, здесь, вероятно, они имеют не сейсмогенную, а оползневую природу, поскольку деформированная толща отличается наклонным залеганием, а складки в основном опрокинуты по падению слоистости.

\section{ОБСУЖДЕНИЕ РЕЗУЛЬТАТОВ}

Механизмы формирования деформационных структур в осадочных отложениях, в частности в слабо литифицированных субаквальных осадках, рассмотрены в большом количестве публикации. К ним относят: подводно-оползневыми процессы, связанные с текучестью осадка на наклонных поверхностях [Alsop et al., 2016], колебания порового давления в осадке, инициированное воздействием сейсмических волн [Hempton and Dewey, 1983; Scott and Price, 1988; Calgue et al., 1992; Lunina, 2019], донных течений и волнений [Alfaro et al., 2002], мутьевых потоков [Allen, Banks, 1972], спонтанные конвективные механизмы при инверсии плотности [Артюшков, 1963; Костяев, 1964; Anketell et al., 1970], в том числе при быстрой седиментации [Kerr and Eyles 1991; Molina et al., 1997], гляциодинамические [Gruszka et. al, 2016] и криогенные процессы [Van VlietLanoe et al., 2004; Горбатов, Колесников, 2019].

Поскольку изученные озерные отложения имеют преимущественно горизонтальную или слабонаклонную слоистость, можно исключить подводно-оползневой механизм их формирования как основной. Например, в изученных слабонаклонных деформационных горизонтах оси складок зачастую наклонены не в направлении, а против падения слоистости (разрез «Тирвас»), отсутствует также корреляция между интенсивностью деформаций и углом наклона слоев, характерная для оползневых нарушений. Только в разрезе «Шарваозеро» (восточный участок) можно предположить некоторую оползневую составляющую, о чем свидетельствуют опрокинутые по падению слоистости складки. Гидродинамические воздействия на озерные осадки в большинстве разрезов также исключены, поскольку слоистость изученных отложений в основном горизонтальная, что соответствует спокойным условиям седиментации. Воздействия волн при формировании изученных озерных осадков на Северо-Западе России маловероятны, т.к. они накоплены в небольших ледниковых бассейнах, зачастую подледных. В Иссык-Кульской впадине деформации часто приурочены к относительно глубоководным фациям, которые формировались ниже базиса воздействия волн. Воздействия мутьевых потоков на осадки также маловероятны, т.к. для таких нарушений следует ожидать наличие в разрезе вергентных лежачих или спиральных складок, образовавшихся в результате латерального течения. Кроме того вверху горизонта деформации должны быть развиты отложения суспензионных потоков, которые имеют гомогенную текстуру или градационную 
слоистость. Гляциодинамические нарушения также полностью исключены, так как эти дислокации не могут быть локализованы в ограниченных стратиграфических интервалах, в которых выявлены изученные деформации.

Вероятность воздействия криогенных процессов на деформированные осадки незначительна ввиду отсутствия в изученных отложениях (в том числе высокодисперсных) обоих регионов характерных посткриогенных текстур - сетчатых, ячеистых, блоковых, а также грунтовых псевдоморфоз по ледяным жилам. Обычно при воздействии криогенных процессов в разрезах наблюдается сопряжение складчатых деформации (криотурбаций) и мерзлотных трещин [Van Vliet-Lanoe et al., 2004]. Кроме того, наиболее значительные криогенные нарушения формируются при перерыве субаквального осадконакопления, а изученные деформации не всегда связанны с внутриформационными несогласиями.

Таким образом, наиболее вероятными механизмами формирования изученных структур путем исключения прочих является самопроизвольная конвективная неустойчивость осадка во время диагенеза и сейсмическое разжижение. Другим возможным механизмом формирования деформации на Балтийском Щите может быть возникновение инверсионного рельефа камовых холмов и гряд. Так, в разрезе камовой гряды «Шарваозеро» нами были описаны деформации инверсионного рельефа камов [Горбатов, 2020], однако, эти структуры в основном развиты на периферии камовой гряды и для них характерны многочисленные разрывные нарушения и общая высокая степень нарушенности осадков (провальные структуры), практические отсутствующие в выше представленных разрезах. В разрезе «Тирвас» триггером конвективной неустойчивости могли быть воздействия течении, о чем свидетельствуют волнистые и косоволнистые текстуры песков, вовлеченных в деформацию.

В работе [Van Vliet-Lanoe et al., 2004] обсуждается различие конволюций в отношении регулярности и пространственного распределения. Показано, что сейсмогенные конволюции имеют большую регулярность и занимают большие пространства, чем спонтанные диагенетические нарушения. Данные выводы не противоречат нашим наблюдениям, хотя региональные различия могут быть обусловлены и разными условиями залегания отложений.

Отдельные работы посвящены выработке диагностических критериев для выделения сейсмогенных конволюций и прочих разновидностей сейсмитов на фоне криогенных и других типов нетектонических нарушений [Лещиков, 2000; Wheeler, 2002; Van Vliet-Lanoe et al., 2004; Van Loon et al., 2020], однако в них недостаточно полно проанализированы связь характера деформации с составом и свойствами деформированных отложений. В ходе настоящего исследования впервые были проведено комплексное литологическое и структурное сравнение деформационных нарушений в двух регионов с сильно различающимися уровнями сейсмической активности, что позволило выявить наиболее устойчивые диагностические признаки как сейсмогенных, так и диагенетических структур - литологические, стратиграфические, морфологические и структурные.

Рассматривая литологическую приуроченность конволюций необходимо заметить, что гранулометрические фракции 0.01-1 мм (от крупнозернистых алевритов до грубозернистых песков) обладают наибольшей способностью к разжижению при вибрационных воздействиях [Tsuchida, Hayashi, 1971; Obermeier, 1996] и являются наиболее подходящими обломочными отложениями для развития не только сейсмитов, но и самопроизвольных конвективных и оползневых деформаций. В таких осадках зерна 
связаны только механически, т.е. между ними отсутствуют физико-химических связи (низкая когезия), как в глинах, но флюидная проницаемость остается еще относительно низкой, по сравнению с крупнообломочными грунтами. Поэтому избыточное поровое давление, возникающие в процессе быстрого или неравномерного осадконакопления или вибрации с воздействием циклических сдвиговых нагрузок рассеивается в них относительно долго, что способствует разжижению грунтов и формированию деформаций. Наши результаты подтверждают эти выводы.

Важный диагностическим параметром конволюций может служить рассматриваемый нами коэффициент синклинальности, который для конволюций конвективного генезиса является показателем соотношения вязкости слоев, на границе которых возникают деформации или его вертикального градиента. Это следует из моделей формирования подобных структур в осадочных породах [Артюшков, 1963; Alfaro et al., 1997]. При этом нормальным соотношением в слабоконсолидированной осадочной толще может считаться залегание наименее уплотненных и вязких осадков на более вязких и консолидированных. При таком соотношении, конволюции связаны с инъекцией более вязкого материала вверх и имеют $\mathrm{K}_{\text {син }}>1$, что может служить диагностическим признаком самопроизвольных конвективных нарушений. Кроме того, поскольку с увеличением глубины следует ожидать уменьшение контрастности вязкости слоев, то сильно сжатые антиклинальные складки

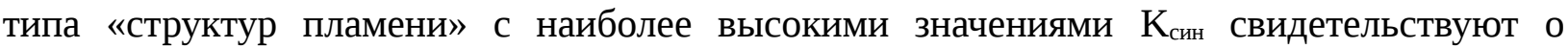
небольшой глубине формирования деформаций. С другой стороны, структуры с $\mathrm{K}_{\text {син }}<1$ с большей вероятностью могут быть сейсмически инициированными конволюциями, поскольку вязкость сейсмически разжиженных осадков, как правило, достигает минимума не на поверхности, а на небольшой глубине [Obermeier, 1996]. Кроме того, при воздействии сейсмических волн на осадки наряду с собственно структурами разжижения возникают нейтральные складки общего укорочения толщи и латерального сжатия типа складок продольного изгиба, которые отличаются $\mathrm{K}_{\text {син }} \sim 1$ (горизонты «А» и «Г» в КокМойнокском разрезе). Подобные структуры не характерны для Балтийского щита.

В работе [Иванов, 1962] показано, что вязкость разжиженных грунтов зависит от размера частиц: чем крупнее частицы и слабее когезия, тем меньше вязкость осадка при деформации. Однако этот показатель сильно зависит и от степени консолидации осадков.

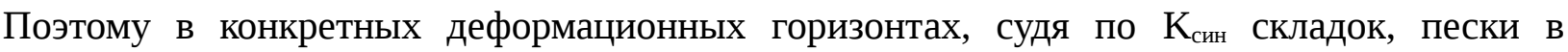
процессе деформации могут иметь вязкость, как ниже (чаще для Балтийского щита), так и выше глин и алевритов. В изученных нами разрезах в целом перекрывающие осадки не зависимо от их состава чаще проявляют меньшую вязкость, чем подстилающие.

Диагностические критерии для выделения сейсмитов в разрезах рыхлых отложений приведены в многочисленных работах [Sims, 1975; Hempton, Dewey, 1983; Obermeier, 1996; Owen, 1996; Wheeler, 2002; Van Vliet-Lanoë et al., 2004; Moretti, Sabato, 2007; Деев и др., 2009; Lunina., Gladkov, 2016; Корженков и др., 2018]. Наиболее важные из них: а) локализация горизонтов деформаций внутри недеформированных слоев; б) латеральная протяженность горизонтов деформаций, указывающая на площадное распространение сейсмических эффектов; в) циклическое повторение конволюций в разрезах, указывающая на повторяемость сейсмических событий; г) исключение атектонических механизмов формирование деформаций, прежде всего, гравитационных и гидродинамических; д) развитие деформации в наиболее разжижаемых осадках; е) сходство деформаций со структурами, полученными экспериментально. На уровне микротекстурных особенностей 
для сейсмогенных конволюций характерны структуры разрыва, укорочения и гофрирования слоев, вращение зерен, микроинъекции, признаки переупаковки скелета осадка [Van Vliet-Lanoë et al., 2004].

Сравнивая конволюции в двух регионах по комплексу общеизвестных критериев сейсмогенности, можно заключить, что деформации на Балтийском щите во многом удовлетворяют этим критериям. Существенные различия есть только в характеристиках латеральной протяженности деформаций и их повторяемости в разрезах. Однако они отражают в больший степени не разный генезис структур, а различные условия залегания вмещающих озерных отложений и разную степень их обнаженности. Вместе с тем, выявленные в ходе исследования дополнительные различия в степени распространенности деформационных структур в зависимости от способности осадков к разжижению и вертикального градиента плотности, а также морфологические особенности деформации, не позволяют относить изученные структуры Балтийского щита к сейсмогенным. Поэтому для надежного различения рассматриваемых структур, на наш взгляд, необходимо ввести ряд дополнительных признаков сейсмогенных конволюций (см. заключение).

В заключении раздела будет уместно привести примеры менее распространенных деформационных структур в осадках Балтийского щита и других платформенных районов, которые принципиально отличаются от рассмотренных в работе конволюций.

В ходе нашего исследования на Балтийском щите лишь в одном разрезе в Южных Хибинах (рабочий карьер на 13 км автодороги Кировск - Коашва) из 15 обследованных разрезов с нарушениями слоистости [Горбатов, Колесников, 2019; Рассказов, Горбатов, 2019], наблюдались значительные деформации, в которых участвовали крупнобломочные отложения. Здесь выявлены разнообразные деформационные структуры на границе галечников и песков флювиогляциального генезиса, причем местами толща деформирована в крупные складки, вероятно гляциотектонической природы (рис. 8). Таким образом, данный разрез слабо сопоставим, с остальными, в которых толща сохраняет ненарушенное залегание, и не представителен для региона.

Регулярные фестончатые складки на границе песков, перекрытых галечниками, описаны также в четвертичных отложениях морского генезиса Большеземельской тундры и интерпретируются как подводно-оползневые [Данилов, 1963].

В приведенных выше примерах, при формировании деформаций разжижение испытывали только подстилающие пески, а лежащие сверху крупнообломочные отложения деформировались пассивно - в результате гравитационного проваливания или заполнения. Таким образом, данные структуры не обязательно связаны с высокой сейсмичностью. Вместе с тем в разрезах Иссык-Кульской впадины деформации крупнообломочных отложений имеют значительно более широкое распространение, чем на Балтийском щите. В других сейсмоактивных регионах (например, Горном Алтае), известны структуры активного восходящего внедрения крупнообломочного материала, например, галечные диапиры в песчаных отложениях [Деев и др., 2015; Deev et al, 2019], образование которых невозможно объяснить без сейсмического разжижения крупнообломочных грунтов.

В Южном Приладожье, в разрезах песчанно-алевритовых бассейновых осадков, вскрытых на берегах рек Свирь и Оять, описаны нетипичные для Балтийского щита складки разжижения в парагенезе со структурами флюидизации, которые отнесены авторами к сейсмитам [Бискэ и др., 2009]. Данные нарушения, действительно контрастно 
выделяются на фоне распространенных в регионе конволюций предполагаемого диагенетического происхождения, в частности деформации формируются в системах без инверсии плотности (алевриты-на-песках), а также имеют морфологию, сближающую их со сейсмитами. Этот пример иллюстрирует необходимость дальнейших исследований по изучению сейсмогенности деформационных структур в озерных комплексах региона.

\section{ЗАКЛЮЧЕНИЕ}

Изученные конволютные структуры в обоих рассматриваемых регионах (Балтийский щит и Тянь-Шань) формировались в результате перехода слабоконсолидированного осадка в разжиженное состояние, на что указывает заметное колебание мощности деформированных слоев, связанное с внутрислойными течениями вязкопластичного материала. Деформации были подвержены водонасыщенные и в разной степени консолидированные осадки, поскольку в нарушенных отложениях слабо развиты структуры разрыва и флюидизации. Результаты исследования показывают, что для возникновения конволюций необходима непрерывная седиментация с изменением состава осадка во времени. Конволютные горизонты не возникают на несогласных границах, поскольку в этом случае до перекрытия вышележащими осадками срезаются верхние горизонты слабоконсолидированных осадков, способных к разжижению.

Основным отличием конволюции в озерных комплексах Балтийского щита и ИссыкКульской впадины является развитие этих структур в осадках весьма ограниченного гранулометрического диапазона (от алевритов до среднезернистых песков) при наличии в разрезах отложений от суглинков до валунников в первых и вовлечение в деформацию практически полного спектра отложений во вторых. Данное отличие позволяет предполагать самопроизвольный (результат гравитационной, в том числе конвективной неустойчивости) генезис конволюций в малосейсмичных регионах, которые развиваются только в тонкозернистых отложениях, наиболее подверженных процессам разжижения при осадконакоплении. В высокосейсмичных регионах формирование конволюций возможно и малоразжижаемых при вибрационных воздействиях отложениях (глинистых и крупнообломочных) за счет значительных внешних динамических воздействий. Существенное генетическое значение имеют и другие отличительные признаки, рассмотренные в работе (табл.), главным образом, различия в плотностной стратификации осадков при формировании конволюций и морфологии складчатых структур.

Проведенное исследование позволяет нам дополнить существующие критерии сейсмогенности конволюций новыми пунктами, имеющих важное практическое значение для анализа подобных структур в регионах с умеренным уровнем сейсмической активности:

1. Возникновение конволюций в осадках широкого гранулометрического диапазона, в том числе относящихся к малоразжижаемым (при вибрационных воздействиях) грунтам (глины и грубообломочные отложения);

2. Возникновение конволюций в стратифицированных осадочных системах без инверсии плотности (например, глины-на-песках), в которых формирование внутрислойных складчатых нарушений не может происходить самопроизвольно. Для этого необходимы значительные вертикальные ускорения при сейсмовибрационных воздействиях. 
3. Наличие среди конволюций не только структур пламени, знаков нагрузки и псевдонодулей, которые могут формироваться без сейсмической инициации, но и столбчатых структур глубокого взаимного внедрения слоев (особенно вергентных), диапиров и кластических даек.

4. Наличие в складчатых горизонтах регулярных складок с отношением ширины синклинальной и антиклинальной части изгиба, не только выше 1 (результат конвективной инъекции в условиях нормального вертикального градиента вязкости), но и ниже 1 (результат сейсмического разжижения осадков при инверсии вязкости и (или) горизонтального укорочения при сейсмовибрацонных воздействиях).

Дальнейшие сравнительные исследования сейсмитов и диагенетических конволюций должны быть направлены на уточнение физических и физико-механических свойств осадков при формировании нарушений обоих типов, воспроизводство и сравнение этих структур методами физического моделирования, а также изучение микротекстурных особенностей деформированных отложений.

Работа выполнена в рамках темы госзадания № 0144-2019-0012 ИФЗ РАН. Авторы признательны А.В. Пономареву, В.А. Камзолкину, А.А. Стрельникову, И.А. Клокову, С.Д. Разумному за содействие в проведении полевых исследований.

\section{ЛИТЕРАТУРА}

Артюшков Е.В. Основные формы конвективных структур в осадочных породах // Докл. АН СССР, 1963, т. 153, № 2, с. 412-415.

Бискэ Ю.С., Сумарева И.В., Щитов М.В. Позднеголоценовое сейсмическое событие в юго-восточном Приладожье. I. Принципы исследования и деформационные текстуры // Вестник Санкт-Петербургского университета. Сер. 7, 2009, вып. 1, с. 3-25.

Ботвинкина Л.Н. Слоистость осадочных пород. - М.: Труды ГИН АН СССР, 1962, вып. 59, 542 с.

Горбатов Е.С., Колесников С.Ф. Деформационные текстуры в озерно-ледниковых отложениях Хибин и оценка их сейсмогенности // Вопросы инженерной сейсмологии, 2016, № 3, с. 5-17.

Горбатов Е.С., Сорокин А.А., Мараханов А.В., Ларьков А.С. Результаты детальных палеосейсмологических исследований в районе полуострова Киндо (Карельский берег Белого моря) // Вопросы инженерной сейсмологии, 2017, № 3, с.5-24.

Горбатов Е.С., Колесников С.Ф. Четвертичные озерные комплексы северо-запада Восточно-Европейской платформы и Северной Якутии и их деформационные структуры // Геофизические процессы и биосфера. 2019, № 4, с. 167-183.

Горбатов Е.С., Колесников С.Ф., Сорокин А.А. Структуры нарушенной слоистости в поздненеоплейстоценовых отложениях Хибинского массива (Кольский полуостров) // Геология и геофизика, 2019, № 5, с. 699-717.

Горбатов Е.С., Разумный С.Д., Стрельников А.А., Родина С.Н. Выявление Чупинской сейсмогенной структуры (Северная Карелия) и параметризация палеоземлетрясений в районе Кандалакшского грабена // Вопросы инженерной сейсмологии, 2020, № 1, с. 24-50.

Горбатов Е.С. Особенности формирования кама «Шарваозеро» (Северная Карелия) и сингенетических деформаций в его разрезе // Геофизические процессы и биосфера, 2020, № 3, с. 33-50.

Данилов И.Д. Водораздельные песчано-галечные отложения Воркутского района. В кн.: Кайнозойский покров Большеземельской тундры. - М.: Изд-во МГУ, 1963, с. 192210. 
Деев Е.В., Зольников И.Д., Гуськов С.А. Сейсмиты в четвертичных отложениях Юго-Восточного Алтая // Геология и геофизика, 2009, т. 50 (6), с. 703-722.

Деев Е.В., Зольников И.Д., Лобова Е.Ю. Позднеплейстоцен-голоценовые сейсмогенные деформации в долине р. Малый Яломан (Горный Алтай) // Геология и геофизика, 2015, № 9, с. 1601-1620.

Иванов П.Л. Разжижение песчаных грунтов. - М.-Л.: Госэнергоиздат, 1962, 260 с.

Корженков А.М., Бауман Д., Омуралиев М., Хасельтон К. Следы древних сильных землетрясений в отложениях озера Иссык-Куль // Известия РГО, 1999, т. 131, вып. 4, c. $48-55$.

Корженков А.М., Абдиева С.В., Агатова А.Р., Р. Арроусмит, Д. Бауман, П.С. Вахрамеева, А.С. Гладков, Б. Гуральник, Е.В. Деев, А.Б. Джумабаева, М. Казмер, Д. Керимбаева, В. Кольченко, К. Кросби, Е.Ю. Лобова (Казанцева), Д.В. Лужанский, Й.В. Мажейка, Э. Мамыров, М.Ю. Меньшиков, Е.А. Морозова, А.М. Муралиев, К. Нурманбетов, Л.А. Орлова, Т.Л. Павлис, И.Э. Поволоцкая, Н. Порат, Е.А. Рогожин, С.Н. Родина, М.В. Родкин, А.А. Сорокин, К. Табалдиев, И.В. Турова, С.Ф. Усманов, А.Б. Фортуна, Т.А. Чаримов, Д. Шен, А.С. Юдахин. Сильные исторические и палеоземлетрясения Прииссыккулья и их положение в структуре Северного Тянь-Шаня. М.: ИФЗ РАН, 2018, 174 с.

Костяев А.Г. О происхождении клиновидных и складчатых деформаций слоев в четвертичных отложениях // Проблемы палеогеографии и морфогенеза в полярных странах и высокогорье. Изд-во МГУ, 1964, с. 131-164.

Никонов А.А. Фенноскандия - недооцененная сейсмогенерирующая провинция // Геофизика XXI столетия. 2002 год: Сб. трудов IV геофиз. чтений им. В.В. Федынского. М.: Научный мир, 2003, с. 207-214.

Николаева С.Б. Сейсмиты в позднеплейстоцен-голоценовых осадках северозапада Кольского региона (северная часть Балтийского щита) // Геология и геофизика, 2009, № 7, с. 830-839.

Поволоцкая И.Э., Корженков А.М., Э.М. Мамыров. Следы сильных землетрясений в озерных осадках Кок-Мойнокской впадины (Северный Тянь-Шань) // Геология и геофизика, 2006, № 9, с. 1024-1035.

Лещиков Ф.Н. Сопряженное положение сейсмических событий и криогенных процессов в Прибайкалье // Сейсмическая опасность и воздействия, Новосибирск, 2000, с. 23-25.

Рассказов А.А., Горбатов Е.С. Лимногеология и эволюция озерного литогенеза. М.: ИФЗ РАН, 2019, 192 с.

Шварев С.В. Постледниковые сейсмогенные деформации озовой гряды в северной части Карельского перешейка // Геоморфология, 2019, №3, с. 19-35.

Alfaro P., Moretti M., Soria J.M. Soft-sediment deformation structures induced by earthquakes (seismites) in pliocene lacustrine deposits (Guadix-Baza Basin, Central Betic Cordillera) // Eclogae geol. Helv., 1997, v. 90, p. 531-540.

Alfaro P., Delgado, J., Estévez, A., Molina, J.M., Moretti, M., Soria, J. Liquefaction and fluidization structures in Messinian storm deposits (Bajo Segura Basin, Betic Cordillera, southern Spain). International Journal of Earth Sciences, 2002, v. 91, p. 505-513.

Allen J.R.L., Banks N.L. An interpretation and analysis of recumbent-folded deformed cross-bedding // Sedimentology, 1972, v. 19, p. 257-283.

Alsop G.I., Marco S., Weinberger R., Levi T. Sedimentary and structural controls on seismogenic slumping within Mass Transport Deposits from the Dead Sea Basin // Sedimentary Geology, 2016, v. 344, p. 71-90.

Anketell JM., Cegla J., Dzulinsky S. On the deformational structures in systems with reversed density gradients. Ann Soc Géol Pologne, 1970, v. 40, p. 3-30. 
Bowman D., Korjenkov A., Porat N. Late-Pleistocene seismites from Lake Issyk-Kul, the Tien Shan range, Kyrghyzstan // Sedimentary Geology, 2004, v. 163, p. 211-228.

Calgue J.J., Naesgaard E., Sy A. Liquefaction features on the Fraser delta: Evidence for Prehistoric earthquakes? // Can. J. Earth Sci, 1992, v. 29, p. 1734-1745.

Deev E.V., Korzhenkov A.M., Turova I., Pavlis, T.L., Luzhanskii D., Mažeika J., Abdieva S., Yudakhin A. Large ancient earthquakes in the western Issyk-Kul basin (Kyrgyzstan, northern Tien Shan) // Journal of Asian Earth Sciences, 2018, v. 166, p. 48-65.

Deev E., Turova I., Borodovskiy A., Zolnikov I., Pozdnyakova N., Molodkov A. Large earthquakes in the Katun Fault zone (Gorny Altai): Paleoseismological and archaeoseismological evidence. Quaternary Science Reviews, 2019, 203, p. 68-89.

Gladkov A.S., Lobova E.U., Deev E.V., Korjenkov A.M., Mažeika J., Abdieva S., Rogozhin E., Rodkin M., Fortuna A.B., Charimov T., Yudakhin A. Earthquake-induced softsediment deformation structures in Late Pleistocene lacustrine deposits of Issyk-Kul Lake (Kyrgyzstan) // Sedimentary Geology, 2016, v. 344, p. 112-122.

Gruszka B., Fard A.M., van Loon A.J. A fluctuating ice front over an esker near Ryssjön (S Sweden) as a cause of a giant load cast // Sediment. Geol., 2016, v. 344, p. 47-56.

Hempton M.R., Dewey J.F. Earthquake-induced deformational structures in young lacustrine sediments, East-Anatolia Fault, Southeast Turkey // Tectonophysics, 1983, v. 98. p. 714.

Kerr M, Eyles N. Storm-deposited sandstones (tempestites) and related ichnofossils of the Late Ordovician Georgian Bay Formation, southern Ontario // Can. J. Earth Sci, 1991, v. 28, p. 266-282.

Lowe D.R. Water escape structures in coarse grained sediments // Sedimentology, 1975, v. 22, p. 157-204.

Lunina O. An overview of clastic dikes: significance for earthquake study // Geodynamics and Tectonophysics. 2019. T.10 (2), p. 483-506.

Lunina O.V., Gladkov A.S. Soft-sediment deformation structures induced by strong earthquakes in southern Siberia and their paleoseismic significance // Sediment Geol, 2016, v. 344, p. 5-19.

Molina J.M., Ruiz-Ortiz P.A., Vera J.A. Calcareous tempestites in pelagic facies (Jurassic, Betic Cordilleras, southern Spain) // Sediment Geol, 1997, v. 109, p. 95-110.

Moretti M., Alfaro P., Caselles O., Canas J.A. Modelling seismites with a digital shaking table // Tectonophysics, 1999, v. 304, p. 369-383.

Moretti M. Soft-sediment deformation structures interpreted as seismites in middle late Pleistocene Aeolian deposits (Apulian foreland, Southern Italy) // Sedimentary Geology, 2000, v. 135, p. 167-179.

Moretti M., Sabato L. Recognition of trigger mechanisms for soft-sediment deformation in the Pleistocene lacustrine deposits of the Sant'Arcangelo Basin (Southern Italy): seismic shock vs. overloading // Sediment. Geol., 2007, v. 196, p. 31-45.

Obermeier S.F. Using Liquefaction-Induced and Other Soft-Sediment Features for Paleoseismic Analysis // Paleoseismology / McCalpin J.P. (ed.). San Diego: Academic Press, 1996, p. 497-564.

Owen G. Experimental soft sediment deformation structures formed by the liquefaction of unconsolidated sands and some ancient examples // Sedimentology, 1996, v. 43, p. 279-293. 318-362.

Shanmugan G. The seismite problem // Journal of Palaeogeography, 2016, T. 5(4), p.

Shanmugan G. Global case studies of soft-sediment deformation structures (SSDS): Definitions, classifications, advances, origins, and problems // Journal of Palaeogeography, 2017. T.6 (4), p. 251-320.

Sims J.D. Determining earthquake recurrence intervals from deformational structures in young lacustrine sediments // Tectonophysics, 1975, v. 29, p. 141-152. 
Scott B., Price S. Earthquake-induced structures in young sediments // Tectonophysics, 1988, v. 147, p. 165-170.

Tsuchida H., Hayashi S. Estimation of liquefaction potential of sandy soils // Proceedings of the Third Joint Meeting, US-Japan Panel on Wind and Seismic Effects, UJNR. Tokyo, 1971, p. 91-101.

Van Loon A.J. Soft-sediment deformation structures in siliciclastic sediments: an overview // Geologos, 2009, v. 15, p. 3-15.

Van Loon A.J. Seismites and their soft-sediment deformation structures // Geologos, 2014, № 2, v. 20, p. 61-166.

Van Loon A.J., Pisarska-Jamrozy M., Woronko B. Sedimentological distinction in glacigenic sediments between load casts induced by periglacial processes from those induced by seismic shocks // Geological Quarterly, 2020, v. 64 (3), p. 000-000.

Vliet-Lanoë B.V., Magyari Á., Meilliez F. Distinguishing between tectonic and periglacial deformations of quaternary continental deposits in Europe // Global and Planetary Change, 2004, v. 43, p. 103-127

Wheeler R.L. Distinguishing seismic from nonseismic soft-sediment structures: Criteria from seismic-hazard analysis // Geological Society of America, 2002, v. 359. p. 1-11. 
Рис. 1. Схемы геологического строения изученных районов. Фрагменты: А взаимное расположение разрезов (показаны звездочками) в районе Балтийского Щита. А1АЗ - крупномасштабные геологические схемы изученных районов и местоположения разрезов $\left(\mathrm{Q}_{3}\right)$, показанных звездочками: 1 - кукисвумская моренная гряда (Южные Хибины), разрез «Тирвас»; 2 - водно-ледниковая гряда «Шарваозеро» с камоподобным расширением (Северная Карелия); 3 - озерно-ледниковая равнина в районе д. Половина (Южная Карелия). Б - геологическая схема Иссык-Кульской внутригорной впадины и расположение разрезов.

1-5 - условные обозначения к схемам A1-А3: 1- дочетвертичные коренные породы, перекрытые чехлом элювиально-коллювиальные отложений; 2-5 - позднеплейстоценголоценовые отложения: 2 - валунная супесчаная морена; 3 - слоистые песчано-гравйногалечные отложения озерно-аллювиального генезиса; 4 - пески озерного или аллювиального генезиса; 5 - песчаные алевриты озерного генезиса. Штриховкой на схеме Б показаны разновозрастные осадки, выполняющие внутригорную впадину.

Рис. 2. Детальная зарисовка обнажения лимно- и флювиогляциальных отложений $\left(\mathrm{Q}_{3}\right)$ с двумя горизонтами конволюций в основании разреза «Тирвас». 1-9 - состав отложений: 1 - галечно-гравийно-песчаный неслоистый материал; 2 - гравий с крупнозернистым песком; 3 - крупнозернистый песок; 4 - среднезернистый песок; 5 мелкозернистый песок; 6 - мелкозернистый песок с алевритом; 7 - алеврит; 8 - ленточный суглинок; 9 - маркирующие прослои алеврита; 10-16 - слоистость: 10 - горизонтальная и слабонаклонная; 11 - пологоволнистая слабосмещенная; 12 - волнистая сильносмещенная: 13 - косоволнистая; 14 - мульдообразная; 15 - косая в слоях; 16 - косая линзовидная; 17-18 - нарушения слоистости: 17 - конволюции (два выдержанных по простиранию горизонта); 18 - субгоризонтальные параллельные разрывы. Врезки (а-д) фрагменты разреза на фотографиях, показанные пунктирными рамками. Цифрами в кружочках (1-8) обозначены слои и пачки слоев, описанные в тексте.

Рис. 3. Схема строения разреза «Шарваозеро» (I) $\left(\mathrm{Q}_{3}\right)$ и зарисовки конволюций (фрагменты с буквенными обозначениями). 1 - пачка гравийно-галечных отложений; 2 крупнозернистые пески с наклонной и косой слоистостью; 3 - мелкозернистые пески с горизонтальной и деформированной слоистостью; 4 - опесчаненные алевриты с горизонтальной и нарушенной слоистостью. Рамки (а-в) - участки конволютного горизонта, показанные на детальных зарисовках. Рамки (в1-в3) - фрагменты участка «в», показанные на фотографиях.

Рис. 4. Два горизонта мелких конволюции в верхнем слое алевритов (1), переслаивающихся со средне-крупнозернистыми песками (2). Разрез Шарваозеро, новый карьер.

Рис. 5. Крупные деформации на границе алевритов (1), перекрытых мелкозернистыми песками (2) в разрезе «Половина» (фрагмент A) ( $\left.\mathrm{Q}_{3}\right)$. Деформированная граница показана пунктирной линией. В ЮВ углу зачистки выявлен субвертикальный разрыв, ограничивающий горизонт конволюций. Стрелками показаны направления течения грунтов. В-С - фрагменты наиболее крупных антиклинальных внедрений алевритов в пески с деталями слоистости вмещающих отложений.

Рис. 6. Литологическая колонка (I) озерных накоплений $\left(\mathrm{Q}_{3}\right)$ в Кок-Мойнокской впадине и характерные конволюции [Корженков и др., 2018], образующие горизонты, фрагменты которых показаны на врезках А-Д: 1 - пролювиальные отложения, 2 галечники, 3 - гравелиты, 4 - песок, 5 - суглинки и глины, 6 - отложения киргизской 
свиты $\left(\mathrm{Pg}_{3}-\mathrm{N}_{1} \mathrm{kr}\right) ; 7$ - горизонты конволюций. Характеристика нарушений в горизонтах А-Д: А - структуры в форме волн; Б - выжимание вверх песчаного слоя в расположенный выше массивный слой глины в форме столбов и грибов; Г - волнообразные конволюции, сформировавшиеся в толще переслаивающихся тонко- и среднезернистых песчаников и глин. Д - зарисовки дивергентных лежачих антиклиналей (Д1, 2), образовавшихся в результате выжимания глин вверх и по латерали - в слой песчаника и фотография ассиметричной лежачей антиклинали (ДЗ).

Рис. 7. Характерные типы сейсмогенных конволюций в позднеплейстоценголоценовых отложениях Иссык-Кульской впадины [Корженков и др., 2018; Deev et al, 2018]: 1 - мергелистые шары, разделенные диапировыми внедрениями разжиженных песков снизу, кровля горизонта деформаций эродирована (A); 2 - глубокое взаимное проникновение мергелей в подстилающий слой крупнозернистого песка с галькой в виде крупных столбов высотой до 60 см, опрокинутых из-за возможного латерального течения разжиженных песков (И), 3 - наклонные столбчатые конволюции типа «выпрыгивающих змей» в отложениях $\left(\mathrm{Q}_{4}\right)$ близ с. Кошкель; 4 - изолированные шары (псевдоконкреции), ранее сложенные песками (вымыты из обнажения) (А); 5 - песчаные диапиры, выжатые в перекрывающие алевриты (Б); 6 - гигантская песчаная подушка со срезанной кровлей в песчано-глинистых отложениях (Ч). Разрезы: А - Актерекский $\left(\mathrm{Q}_{3}\right)$; Б - БозБармакский $\left(\mathrm{Q}_{3}\right)$; И - Ирдыкский $\left(\mathrm{Q}_{3}\right)$; Ч - Чоктальский $\left(\mathrm{Q}_{4}\right)$.

Рис. 8. Деформационные структуры в сложно дислоцированных крупнообломочных отложениях в разрезе флювиогляциального комплекса (Южные Хибины) ( $\left.\mathrm{Q}_{3}\right)$. а переслаивание дислоцированных песков и галечников, б - внедрение галечников в подстилающий слой песков в форме штока, в - деформация линзы гравия с мелкими протрузиями на границе с песками, г - кластическая дайка в слое песков и линзе гравия. 
Табл.

Сравнение конволютных структур в озерных отложениях рассматриваемых регионов

\begin{tabular}{|c|c|c|c|c|}
\hline Регион & $\begin{array}{lr}\text { Особенности } & \text { залегания и } \\
\text { строения } & \text { горизонтов } \\
\text { деформаций } & \end{array}$ & $\begin{array}{l}\text { Морфология } \\
\text { структурные } \\
\text { особенности } \\
\text { конволюций }\end{array}$ & $\begin{array}{l}\text { Состав и п плотностная } \\
\text { стратификация } \\
\text { деформированных отложений }\end{array}$ & $\begin{array}{l}\text { Основной } \\
\text { процесс } \\
\text { формирования } \\
\text { конволюций }\end{array}$ \\
\hline $\begin{array}{l}\text { Балтийски } \\
\text { й щит - со } \\
\text { слабой } \\
\text { сейсмично } \\
\text { стью }\end{array}$ & $\begin{array}{l}\text { Мощность 5-120 см, } \\
\text { латеральная } \\
\text { протяженность - до } 10 \text { м, } \\
\text { повторяемость в разрезе - } \\
\text { 1-5 горизонтов / метр. } \\
\text { Выступающие части } \\
\text { складок, как правило, не } \\
\text { размыты и перекрыты } \\
\text { гомогенным материалом в } \\
\text { верхней части горизонта. }\end{array}$ & 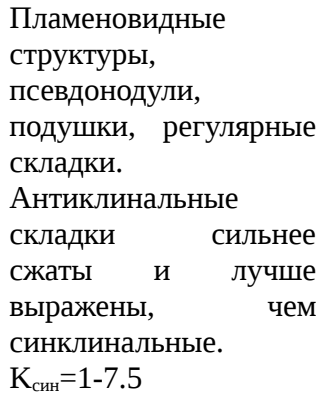 & 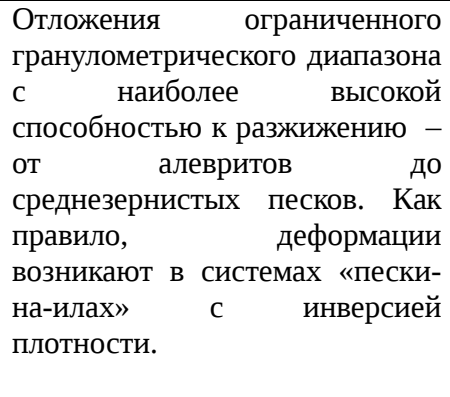 & $\begin{array}{l}\text { Самопроизвольн } \\
\text { ая конвективная } \\
\text { неустойчивость с } \\
\text { оползневой } \\
\text { составляющей. }\end{array}$ \\
\hline $\begin{array}{l}\text { Иссык- } \\
\text { Кульская } \\
\text { впадина - с } \\
\text { высокой } \\
\text { сейсмично } \\
\text { стью }\end{array}$ & $\begin{array}{l}\text { Мощность 15-200 см, } \\
\text { латеральная } \\
\text { протяженность - до } \\
\text { первых сотен метров, } \\
\text { повторяемость в разрезе - } \\
0.1-10 \text { горизонтов / метр. } \\
\text { Складки в кровле могут } \\
\text { быть, как } \\
\text { эродированными, так и не } \\
\text { размытыми. }\end{array}$ & 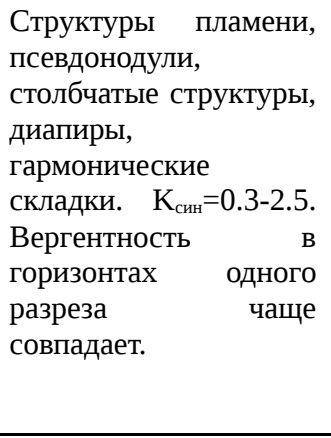 & 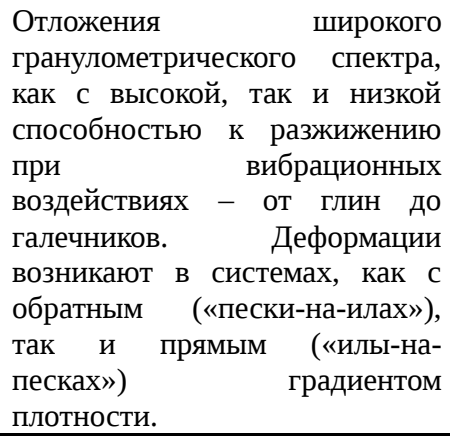 & $\begin{array}{l}\text { Сейсмическое } \\
\text { разжижение и } \\
\text { изгибные } \\
\text { дислокации при } \\
\text { вибрационных } \\
\text { воздействиях. }\end{array}$ \\
\hline
\end{tabular}

Примечание: $\mathrm{K}_{\text {син }}$ (коэффициент синклинальности) - отношение длин синклинальных и антиклинальных складок в горизонте конволюций. 

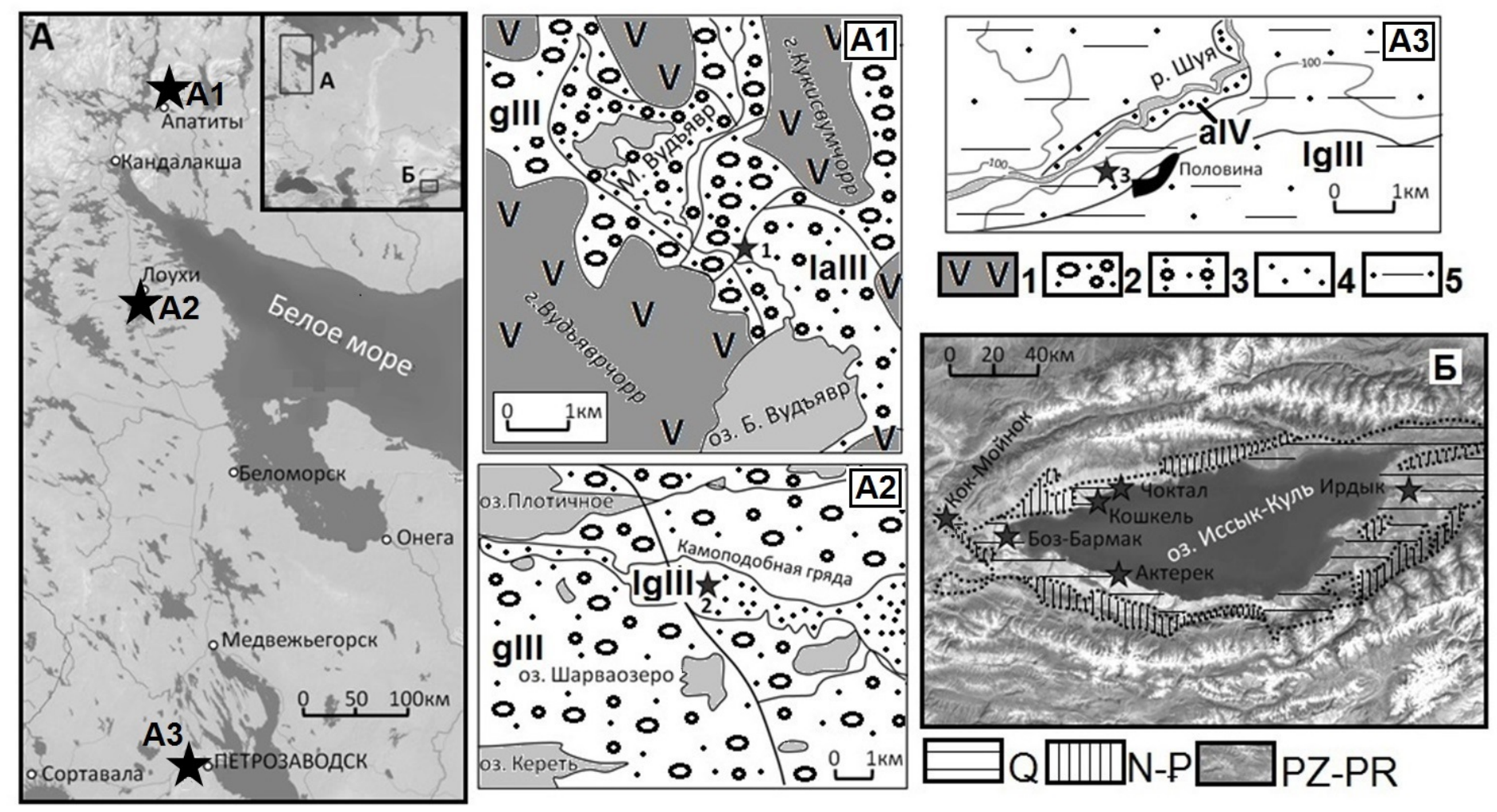

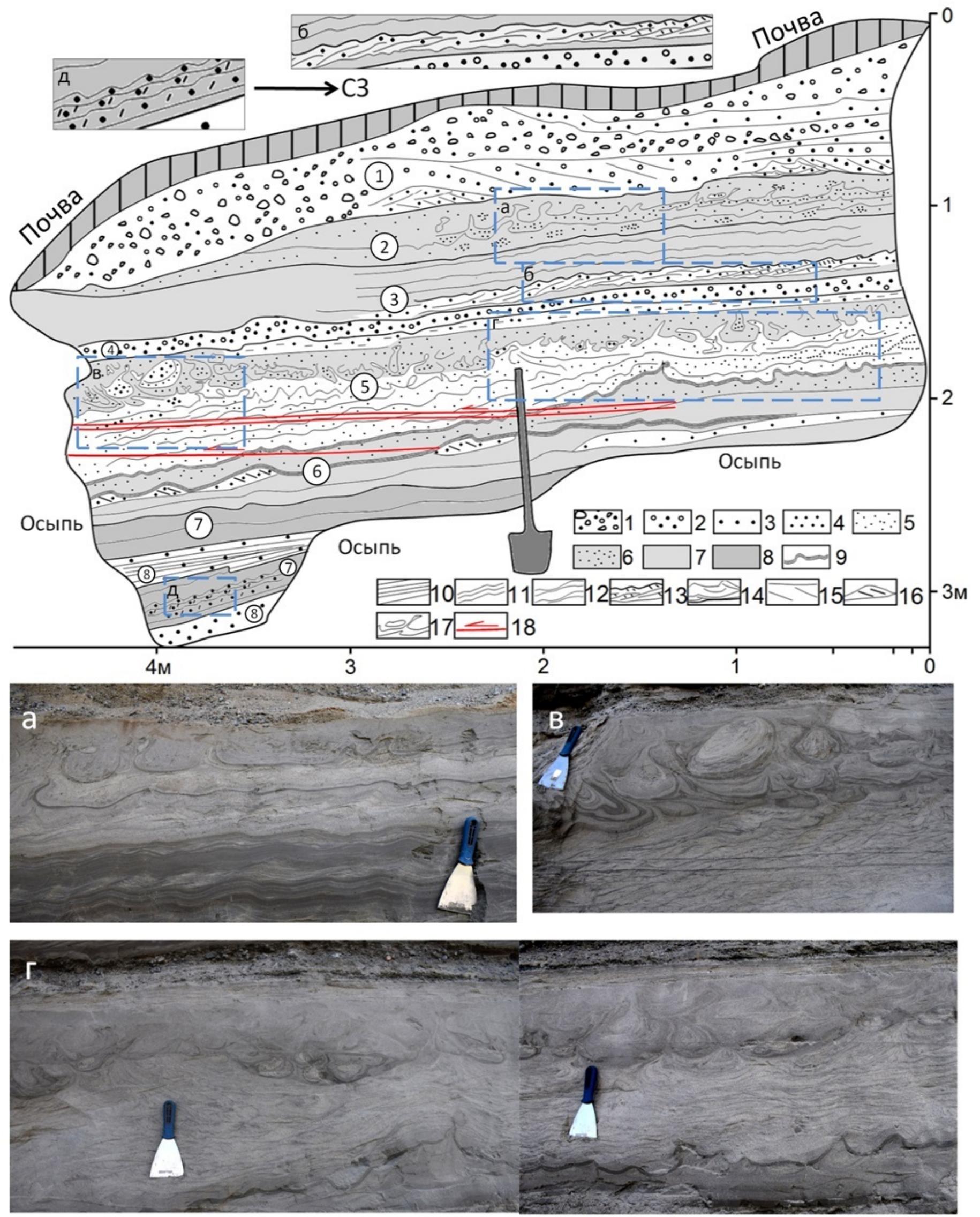

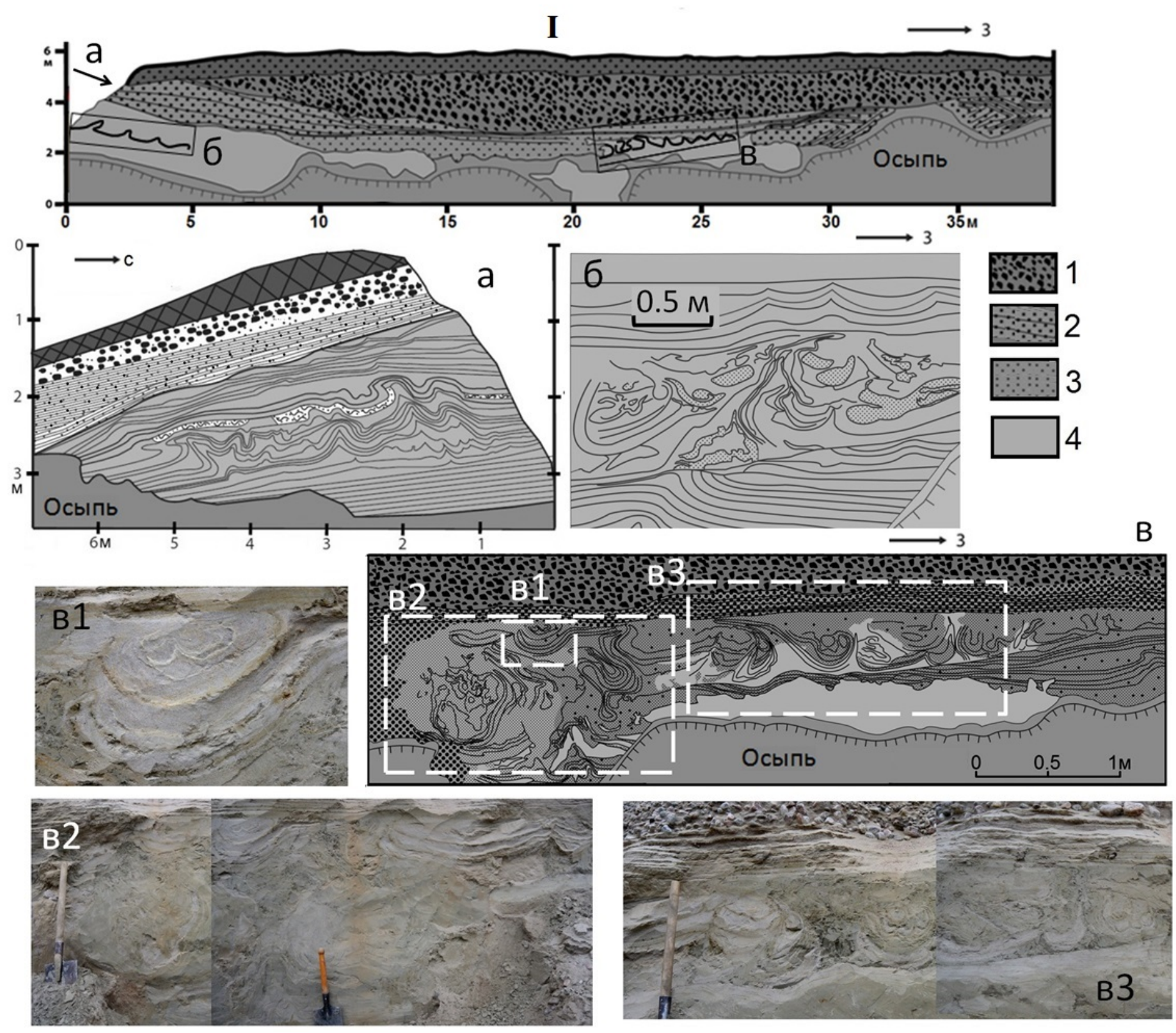


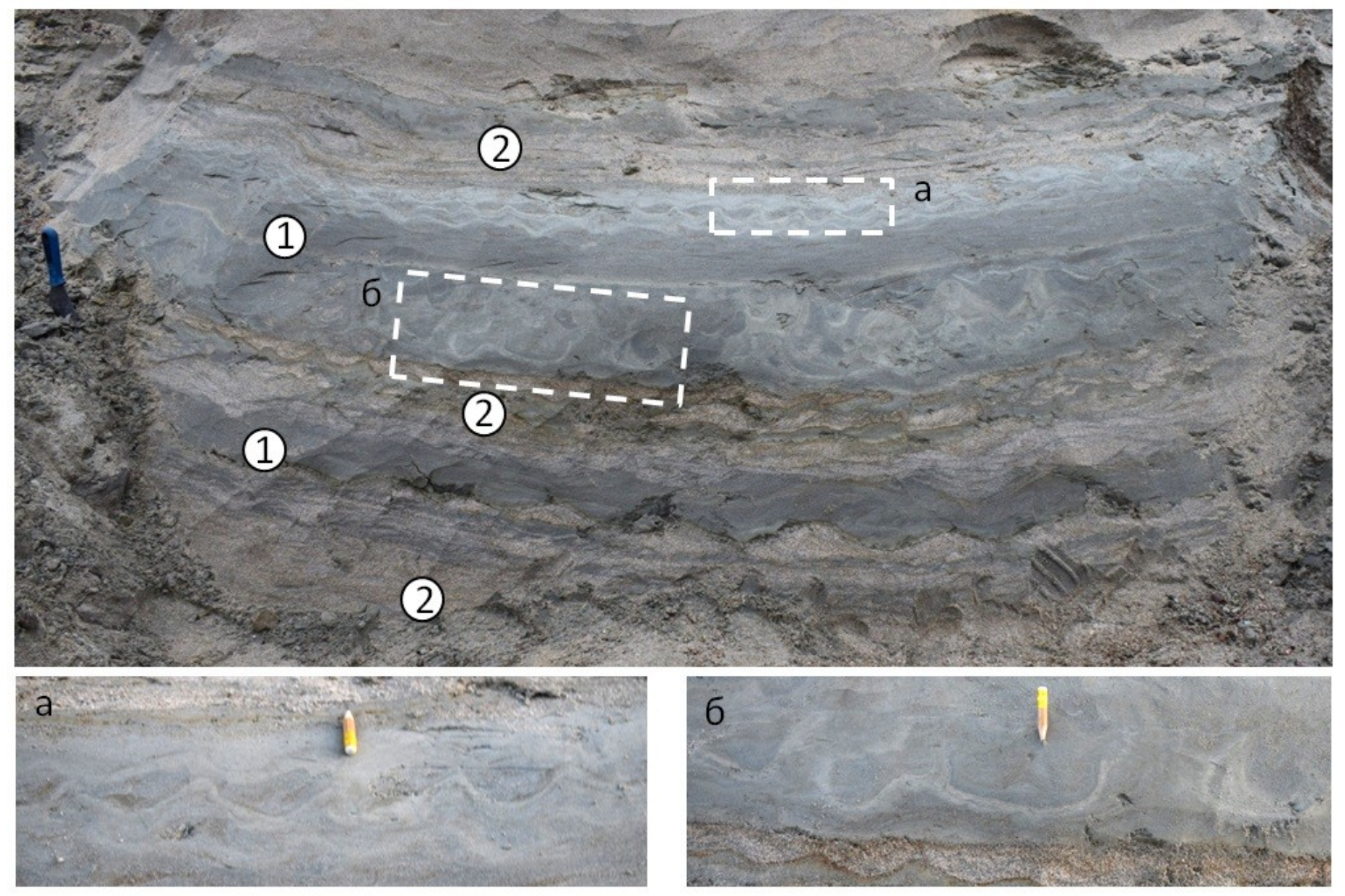



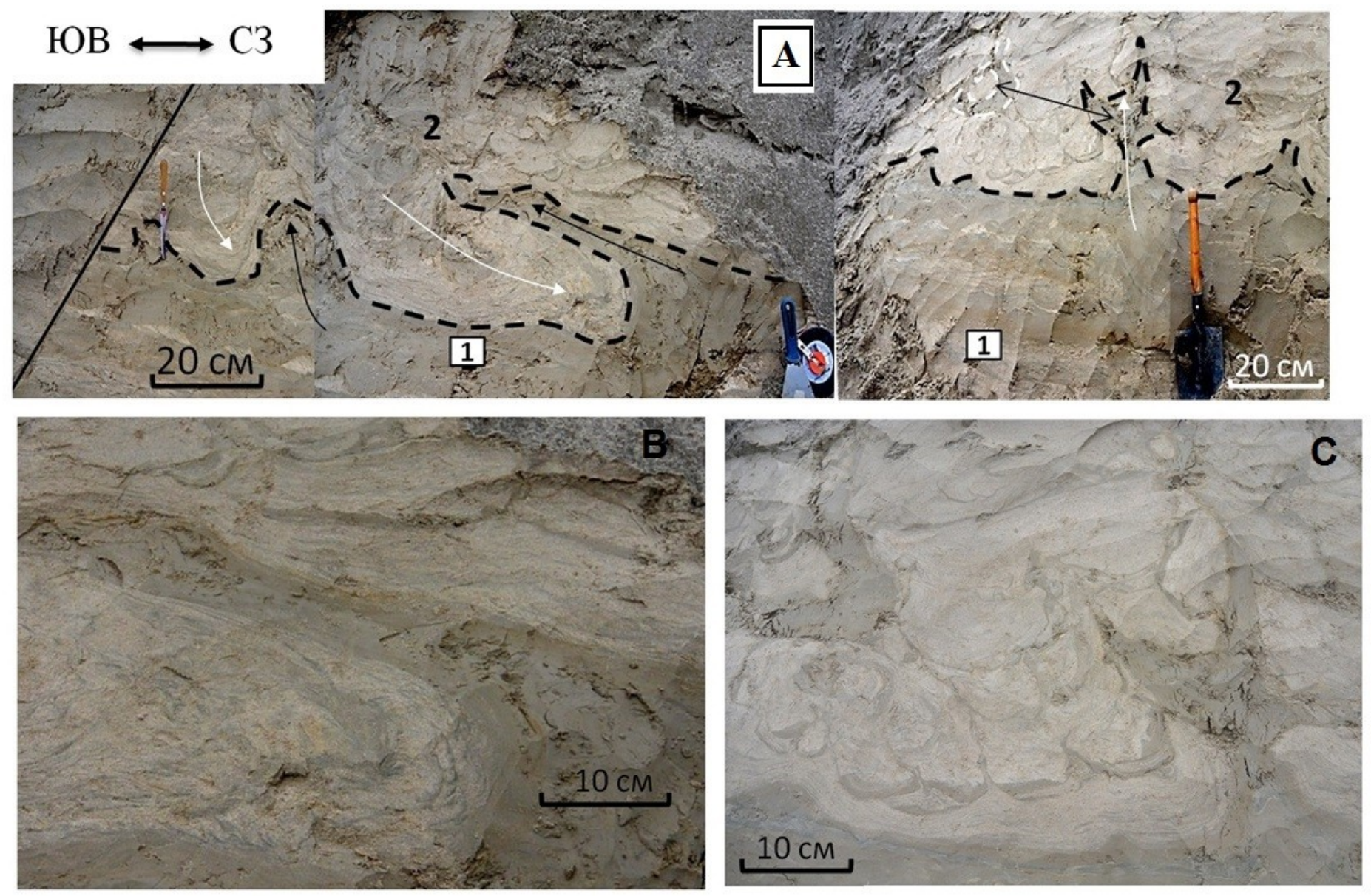


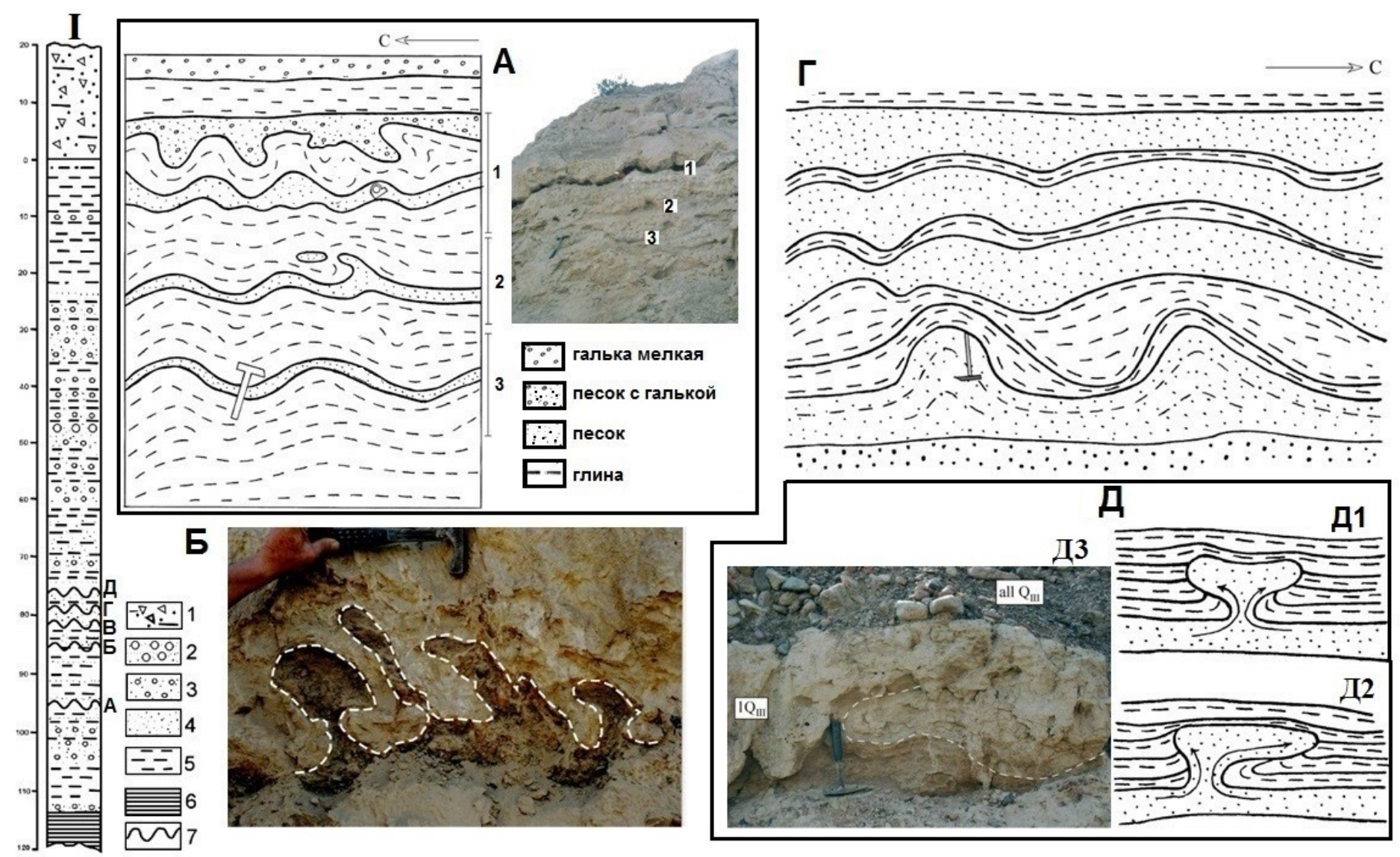



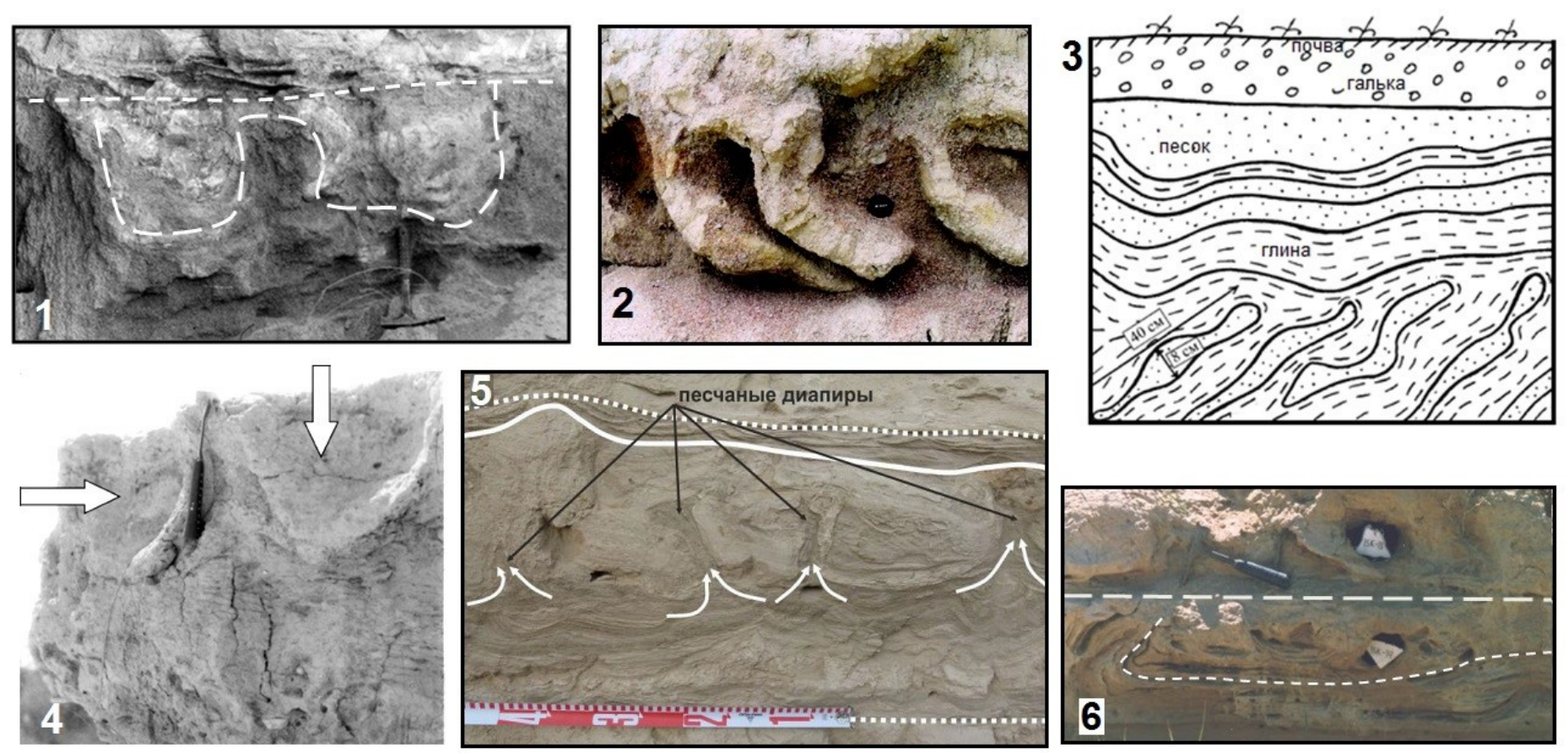

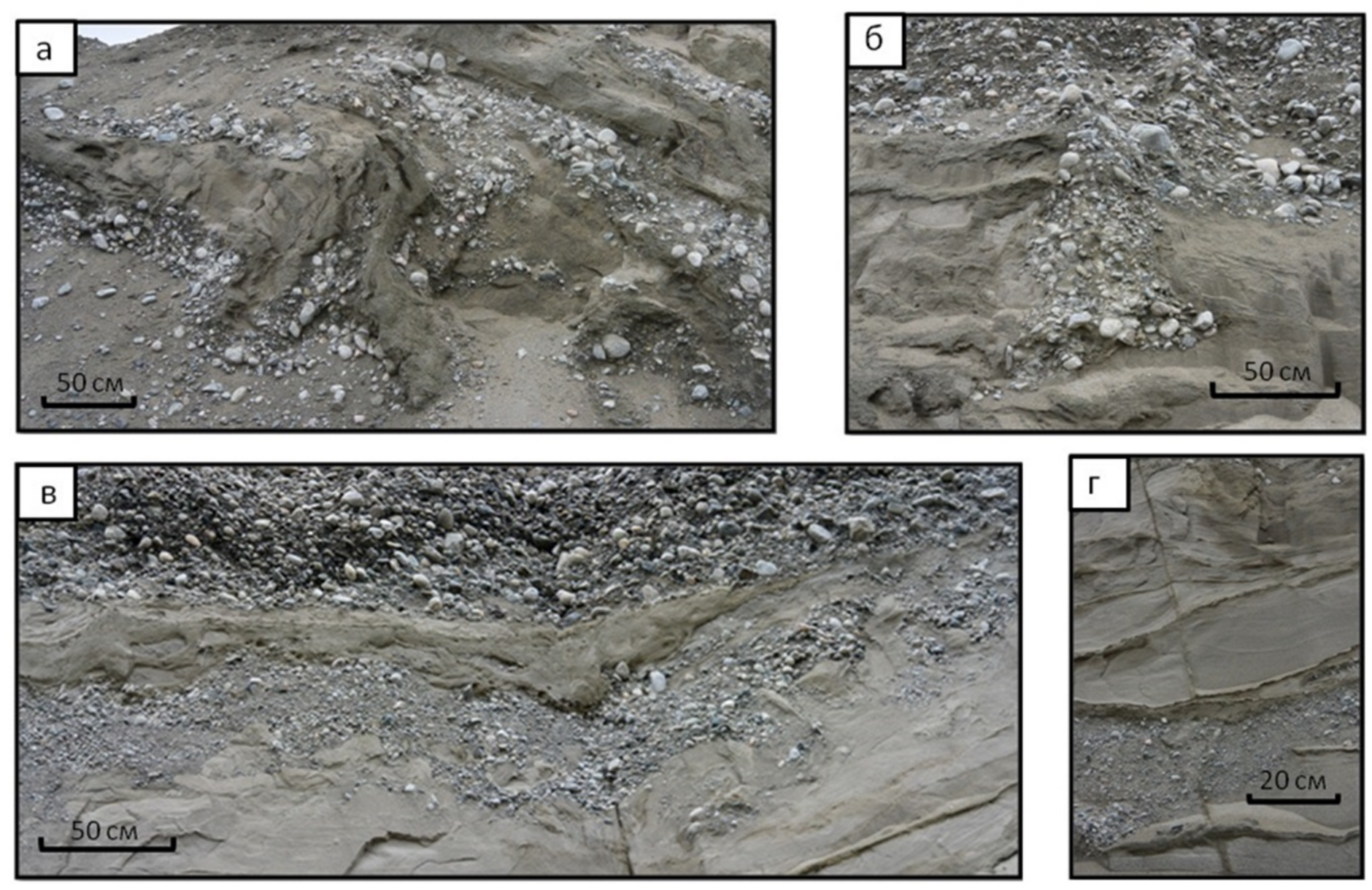